1 A lower crust origin for some flood basalts of the Emeishan large igneous province,

\title{
SW China
}

\section{J. GREGORY SHELLNUTT ${ }^{1}$, TADASHI USUKI ${ }^{2}$, ALLEN K. KENNEDY ${ }^{3} \&$ HAN-YI CHIU $^{1}$}

${ }^{1}$ National Taiwan Normal University, Department of Earth Sciences, 88 Tingzhou Road Academia Road Section 4, Taipei 11677, Taiwan

${ }^{2}$ Academia Sinica, Institute of Earth Sciences, 128 Academia Road Section 2, Taipei 11529, Taiwan

${ }^{3}$ Curtin University, Department of Applied Physics, Kent Street, Bentley, Western Australia 6102, Australia

*Corresponding author (e-mail: jgshelln@ntnu.edu.tw)

Abstract: High seismic velocity layers within the lower crust (i.e. $\sim 40 \mathrm{~km}$ ) of the Yangtze Block are interpreted as mafic underplated rocks derived from the Emeishan mantle plume. However the region experienced a previous magmatic event during the Neoproterozoic ( 800 Ma) which produced the Kangdian basalts and associated mafic intrusions. The identification of inherited Neoproterozoic (i.e. $\sim 750$ to $\sim 850 \mathrm{Ma})$ zircons within Emeishan magmatic rocks indicates they either assimilated older material during emplacement or that they were derived from Neoproterozoic basement rocks of the Yangtze Block. Equilibrium partial melt modeling of Neoproterozoic Kangdian basalts can produce compositions similar to Emeishan basalt at a pressure of $1.2 \mathrm{GPa}$ (i.e. $~ 40 \mathrm{~km}$ depth). The models indicate that is possible some magmatic rocks, including the flood basalts, of the ELIP are the product of partial melting of Neoproterozoic mafic rocks that underplated the lower crust of the Yangtze Block. Thus it is possible that some Emeishan basalts are the product of mafic lower crust recycling.

Supplementary material: The results of MELTS modeling are available at www.geolsoc.org.uk/SUPXXX 
26 The Late Permian Emeishan flood basalts of SW China are the most voluminous rock-type of the 27 Emeishan large igneous province (ELIP) which is one of at least five major eruptions of mafic continental volcanic rocks that occurred during the Late Palaeozoic (i.e. Tarim LIP, Siberian Traps,

Panjal Traps, Skagerrak-Centred LIP). Like many continental flood basalts they are compositionally divided into 'high-Ti' and 'low-Ti' groups which are interpreted to reflect different petrological origins. The 'high-Ti' (i.e. $\mathrm{TiO}_{2}>2.5 \mathrm{wt} \%$ ) basalts are interpreted to be derived by low degrees $(<8 \%)$ of partial melting of a mantle plume source whereas the formation of the 'low-Ti' basalts (i.e. $\mathrm{TiO}_{2}<$ $2.5 \mathrm{wt} \%$ ) is more complex and are suggested to be derived from the sub-continental lithospheric mantle (SCLM), or picritic magmas that assimilated upper crust, or the same source as the high-Ti basalts but merely represent higher degrees (i.e. 10-15\%) of partial melting (Xu et al. 2001; Song et al. 2001, 2004, 2008a, b; Hanski et al. 2004; Xiao et al. 2004; Hou et al. 2006; Wang et al. 2007; Fan et al. 2008; Zhou et al. 2008; Shellnutt \& Jahn 2011; Wang et al. 2011).

The ELIP is considered to be one of the best examples of a mantle plume derived large igneous province because there is evidence for pre-volcanic uplift, presence of ultramafic volcanic rocks (i.e. picrites), and short eruption duration of voluminous flood basalts (He et al. 2003; Hanski et al. 2004; Ali et al. 2005; Campbell 2005, 2007; Shellnutt et al. 2012; Shellnutt 2014). One of the most intriguing interpretations of the ELIP mantle plume model is related to the identification of high seismic velocity layers within the lower crust of the Yangtze Block beneath the region considered to be the epicenter of magmatism. The same region is interpreted to have thicker average crust than other regions of the western Yangtze Block (Xu et al. 2004; Xu and He 2007; Chen et al. 2010). Xu et al. (2004) interpreted the deep (i.e. > $100 \mathrm{~km}$ ) high seismic velocity layers to be the fossilized Emeishan mantle plume head whereas the lower crust (i.e. $40 \mathrm{~km}$ to $60 \mathrm{~km}$ ) high velocity layers are interpreted to be the underplated mafic and ultramafic rocks which fed the surface flows and shallow crustal intrusions. The seismic data interpretations coupled with the crustal thickness is a compelling explanation for and is 
consistent with the expectation of a mantle plume-derived large igneous province. However there is

another equally valid interpretation of the high seismic velocity layers if they represent underplated mafic rocks.

The western margin of the Yangtze Block was the site of either long-lived subduction-related magmatism or mantle plume-related magmatism during the Neoproterozoic (Li et al. 1999; Zhou et al. 2002a, b; Zhao \& Zhou 2007). The Neoproterozoic ( 800 Ma) Kangdian basalts are located at the western boundary of the Yangtze Block within the Kangdian rift and are found within the same geographic area as the Emeishan basalts. The basalts and associated mafic dykes and plutonic rocks are described by Li et al. (2002) as being compositionally similar to continental flood basalts from Ethiopia and/or alkali basalts of Hawaii. In the case of the Kangdian basalts, they are interpreted to be derived from an OIB-like mantle plume source associated with the break-up of Rodina whereas similarly aged granitic rocks and younger (i.e. $\sim 750 \mathrm{Ma}$ ) gabbros in the same region are interpreted to be related to an active continental margin setting (Li et al. 2002, 2005, 2006; Zhou et al. 2002a, b; Zhou et al. 2004; Lin et al. 2007; Zhao \& Zhou 2007; Zhao et al. 2008; Wang et al. 2009; Wang et al. 2010). Regardless of how the Kangdian or other Neoproterozoic rocks formed (i.e. subduction zone setting vs. mantle plume), it is possible that magmas accumulated in the lower crust of the Yangtze Block and thus the crustal seismic layers may not be completely attributed to the ELIP. In fact, the seismic layers could represent a mixture of mafic and ultramafic material from both the Kangdian event and the Emeishan event.

In this paper we show the results of in situ zircon $\mathrm{U} / \mathrm{Pb}$ dating and $\mathrm{Hf}$ isotopes of inherited Neoproterozoic zircons from Late Permian granitic rocks of the ELIP. We discuss the origins of the older zircons and evaluate the possibility that some ELIP-related magmatic rocks, including the flood basalts, may be derived by partial melting of rocks similar in composition to the Neoproterozoic Kangdian basalts. 
76 The Late Permian Emeishan large igneous province (ELIP) is located in southwestern China on the

77 western edge of the Yangtze Block near the boundary with the Early Triassic Songpan-Ganze terrane

78 (Fig. 1a). The distribution of ELIP rocks was affected by faulting associated with the accretion of the

79 Songpan-Ganze terrane and later during the Paleogene collision of India and Eurasian and covers an

80 area of at least $0.3 \times 10^{6} \mathrm{~km}^{2}$ including the Song Da zone of northern Vietnam which was translated

$81 \sim 600 \mathrm{~km}$ along the Ailao Shan-Red River shear zone during the Oligocene (Chung \& Jahn 1995;

82 Chung et al. 1997). The ELIP is subdivided into three structural zones (i.e. inner, intermediate and

83 outer) based on crustal thickness estimates using seismic profiling (Figs. 1a, b). The inner zone of the

84 ELIP is interpreted to have the thickest crust which thins radial to the outer zone (Xu et al. 2004). The volcanic succession ranges from a maximum thickness of $\sim 5 \mathrm{~km}$ in the inner zone to $<1 \mathrm{~km}$ at the margin of the outer zone. The volcanic rocks consist mostly of flood basalts but there is a higher proportion of picrites found in the lower flows of the inner zone whereas basaltic andesites and silicic volcanic rocks are common within the upper flows throughout the ELIP. The inner zone, chiefly the Panxi region, contains many giant orthomagmatic Fe-Ti-V oxide deposits whereas Ni-Cu-(PGE) and PGE deposits are found within the inner zone and outer zone but none have been found within the intermediate yet (Shellnutt 2014). The Yangtze Block was located at equatorial latitudes of eastern Pangaea and the volcanic rocks of the ELIP erupted on top of middle Permian limestones or directly on to Precambrian cratonic rocks.

The granitic plutons of this study are from the Song Da zone of northern Vietnam and the Panxi region in Sichuan. Northern Vietnam is part of the South China block, which is separated from the Indochina block by the Song Ma suture zone to the southwest (Fig. 1). The SW side of the ASRR shear zone consists of the Phan Si Pan uplift and Tu Le basin, which are further surrounded by Song Da belt in the west (Fig. 2). The Song Da zone rocks are from the Phan Si Pan uplift and Tu Le basin and are 
correlative with the inner zone of the ELIP. The area is crosscut by the left-lateral ASRR shear zone for

100 over $1000 \mathrm{~km}$ from SE Tibet to the South China Sea (Tapponnier et al. 1990; Leloup et al. 1995;

101 Chung et al. 1997). The Phan Si Pan uplift consists mainly of alkaline and sub-alkaline granitoids

102 whereas the Song Da belt consists of picrite, flood basalt and rhyolitic rocks (Hanski et al. 2004; Wang

103 et al. 2007; Anh et al. 2011). The volcanic rocks of the Song Da belt rest on early Permian limestone

104 and are unconformably overlain by Triassic limestone and coal-bearing shale (Anh et al. 2011).

105 Two granitic plutons from the Panxi region of the ELIP were selected for this study (Fig. 3). The 106 peraluminous Yingpanliangzi pluton is located within the city of Panzhihua just south of the Jinsha

107 River and intrudes Proterozoic granitic gneisses (Shellnutt et al. 2011a). The pluton is exposed along a

108 dirt road revealing fresh, albeit sporadic outcrops that contain ellipsoidal microgranular enclaves that

109 are more mafic than the host rock. The pluton is known to be younger than $\sim 600$ Ma because dykes

110 emanating from the main exposure are observed cutting the Denying ( 600 Ma) marble. The sample

111 (GS03-065) dated for this study is located at $26^{\circ} 333^{\prime} 36^{\prime \prime} \mathrm{N}, 101^{\circ} 42^{\prime} 53^{\prime \prime}$ E. The peralkaline Panzhihua

112 granite is located (i.e. $26^{\circ} 34^{\prime} 29^{\prime \prime} \mathrm{N}, 101^{\circ} 37^{\prime} 38^{\prime}$ ' E) to the west of the Yingpanliangzi pluton and

113 intruded Emeishan flood basalt. The Panzhihua granite is interpreted to be petrogenetically related to

114 the Panzhihua layered gabbroic intrusions which hosts a world-class Fe-Ti-V oxide deposit (Shellnutt

115 \& Jahn 2010).

116

\section{Methods}

118 Zircon U/Pb SHRIMP II ages

119 Zircon grains were separated using conventional heavy liquid and magnetic techniques, mounted in

120 epoxy, polished, coated with gold, and photographed in transmitted and reflected light to identify

121 grains for analysis. $\mathrm{U} / \mathrm{Pb}$ isotopic ratios of zircons from sample GS03-065 (i.e. peraluminous granite)

122 were measured using the SHRIMP II at Curtin University of Technology in Perth, Western Australia. 
123 The measured isotopic ratios were reduced off-line using standard techniques (Claoué-Long et al.

124 1995) and the $\mathrm{U} / \mathrm{Pb}$ ages were normalized to a value of $564 \mathrm{Ma}$ determined by conventional U-Pb

125 analysis of zircon standard $\mathrm{CZ3}$. Common $\mathrm{Pb}$ was corrected using the methods of Compston et al.

126 (1984). The ${ }^{206} \mathrm{~Pb} /{ }^{238} \mathrm{U}$ and ${ }^{207} \mathrm{~Pb} /{ }^{235} \mathrm{U}$ data were corrected for uncertainties associated with the

127 measurements of the CZ3 standard. The ${ }^{207} \mathrm{~Pb} /{ }^{206} \mathrm{~Pb}$ ages given in table 1 are independent of the 128 standard analyses.

129 Zircon analyses for sample GS03-010 (i.e. peralkaline granite) were measured using the 130 SHRIMP II at Chinese Academy of Geological Sciences, Beijing, China. The measured isotopic ratios 131 were reduced off-line using standard techniques and calibrated to the TEMORA 1 standard which was 132 repeatedly analyzed after every three zircon analyses (Claoué-Long et al. 1995; Black et al. 2003a, b).

133 Common $\mathrm{Pb}$ was corrected using the methods of Compston et al. (1984). The ${ }^{206} \mathrm{~Pb} /{ }^{238} \mathrm{U}$ and ${ }^{207} \mathrm{~Pb} /{ }^{235} \mathrm{U}$ 134 data were corrected for uncertainties associated with the measurements of the TEMORA 1 standard. 135 The ${ }^{206} \mathrm{~Pb} /{ }^{238} \mathrm{U}$ and ${ }^{207} \mathrm{~Pb} /{ }^{235} \mathrm{U}$ data are found within table 1.

\section{Zircon Hf LA-ICP-MS values}

138 Hf isotopes were analyzed using a Nu Plasma multi-collector ICP-MS attached to a New Wave 139 UP213 laser-ablation microprobe housed at the Institute of Earth Science, Academia Sinica, Taipei, 140 documented in Lan et al. (2009). The analytical procedure follows that described in Griffin et al. (2000, 141 2004). The Hf isotopes were measured on the dated spots of individual zircons to minimize zoning 142 effect but the laser ablation size is $55 \mu \mathrm{m}$, slightly larger than that of preexisting spots by the U-Pb 143 dating. Data were normalized to ${ }^{179} \mathrm{Hf} /{ }^{177} \mathrm{Hf}=0.7325$, using an exponential correction for mass bias. $144{ }^{176} \mathrm{Hf} /{ }^{177} \mathrm{Hf}$ results of Mud Tank and Harvard zircon standards during analysis of this study are $1450.282530 \pm 0.000050(2 \sigma, \mathrm{n}=63)$ and $0.282314 \pm 0.000088(2 \sigma, \mathrm{n}=22)$, respectively. $\varepsilon \mathrm{Hf}_{(\mathrm{T})}$ values 146 and model ages used in the figures were calculated using the decay constant $\left(1.867 \times 10^{-11}\right.$ per year $)$ 
147 proposed by Söderlund et al. (2004). The single stage deplete-mantle model ages ( $\left.T_{\mathrm{DM} 1}\right)$ and the two-

148 stage model ages $\left(T_{\mathrm{DM} 2}\right)$ are calculated. We assumed that ${ }^{176} \mathrm{Lu} /{ }^{177} \mathrm{Hf}$ of average continental crust is

1490.015 (Griffin et al. 2004) for calculation of $T_{\mathrm{DM} 2}$. The results are found within table 2.

150

$151 \quad$ Results

152 In situ zircon $\mathrm{U} / \mathrm{Pb}$ ages

153 GS03-065 contains zircons with a variety of textures and morphologies. The CL images, Figure

1544 show the highly complex internal structure of these zircons. Many zircons exhibit varying degrees of

155 recrystallization. Some have only a thin overgrowth of intermediate U zircon on the rim of crystals,

156 while others have embayments of both high $U$ and low $U$ zircon intergrown within a single crystal (Fig.

$1574 a)$. The low $U$ region in this grain has a ${ }^{206} \mathrm{~Pb} / 238 \mathrm{U}$ age of $555 \mathrm{Ma}$. In figure $4 \mathrm{~b}$, the zircon shows

158 three distinct growth zones. An inner low $\mathrm{U}$ region is surrounded by oscillatory moderate $\mathrm{U}$ zircon and

159 the very centre of the crystal shows a small, higher $U$ region. The oscillatory zoned region has a

$160{ }^{206} \mathrm{~Pb} / 238 \mathrm{U}$ age of $671 \mathrm{Ma}$, while the core age is $701 \mathrm{Ma}$. There is a progression of recrystallization

161 effects in larger zircons through the two stages shown figure 4. Small, high-U zircons no longer show

162 any oscillatory zoning and have had their ages reset to varying degrees. The lowest $206 \mathrm{~Pb} / 238 \mathrm{U}$ age,

$163485 \mathrm{Ma}$, was found in a small, $25 \mathrm{um}$, high-U (897 ppm) grain. The oldest $206 \mathrm{~Pb} / 238 \mathrm{U}$ age in this

164 population, $787 \mathrm{Ma}$, was found in a moderate-U (298 ppm) grain which was unzoned. Not all grains

165 have been completely recrystallized or had their ages reset, but there is a strong inverse relationship

166 between U content. Figure 5a gives an overview of the SHRIMP results for GS03-065 plotted on a

167 concordia diagram. Most of analyses plot along a chord with calculated intersections at $264 \pm 82 \mathrm{Ma}$

168 and $806 \pm 36 \mathrm{Ma}$. The upper intersect is the best estimate of the original protolith crystallization age.

169 The lower intercept is identical to that of the mafic-ultramafic and syenite intrusions in the ELIP, which

170 have ages of $\sim 260 \mathrm{Ma}$ and suggests this is the age of the thermal event affecting the recrystallization of 
171 the zircons (Shellnutt et al., 2012). The data for this sample is consistent with partial

172 metamorphic/igneous resetting of zircon ages, with the high-U zircons ages being more susceptible to 173 disturbance.

174 Four inherited zircons were analyzed from sample GS03-010. The crystals are typically 175 between $30 \mu \mathrm{m}$ to $50 \mu \mathrm{m}$ and show oscillary zonation and have variable morphologies. The internal 176 structure is less complicated than those from GS03-065 and they are of igneous origin (i.e. $\mathrm{Th} / \mathrm{U} \leq 1$ ).

177 Figure 5b show the SHRIMP results for GS03-010 plotted on a concordia diagram. Two of the analyses 178 plot along the concordia whereas the other two have suffered $\mathrm{U}$ loss. The concordant ${ }^{206} \mathrm{~Pb} /{ }^{238} \mathrm{U}$ ages 179 are $860 \pm 7 \mathrm{Ma}$ and $854 \pm 8 \mathrm{Ma}$ but the intercept age of all analyses is $848 \pm 45 \mathrm{Ma}$.

180

181 In situ zircon $H f$ isotopes

182 Hf isotope compositions were analyzed for 18 inherited zircons from the Phan Si Pan granites (table 2).

183 The Neoproterozoic zircons yield Hf isotope compositions in the range of 0.282173 to 0.282299 . The 184 zircons have mostly negative $\mathrm{EHf}_{(\mathrm{T})}$ values with a few moderately positive values and range between 1855.4 and +1.7 which correspond to $T_{\mathrm{DM} 1}$ model ages between $1.14 \mathrm{Ga}$ to $1.51 \mathrm{Ga}$. The relatively enriched 186 Hf isotope values indicate that they are either derived from a crustal source or an enriched mantle 187 source.

188

189 Discussion

190 Inherited zircons within plutonic rocks of the Emeishan large igneous province

191 Shellnutt \& Zhou (2007) and Shellnutt et al. (2011a) showed that the alumina saturation index (i.e. ASI $192=\mathrm{Al} / \mathrm{Ca}+\mathrm{Na}+\mathrm{K})$ offers a simple and relatively robust petrogenetic classification scheme for the 193 Emeishan granitoids. The peralkaline granitoids are interpreted to be derived by fractional 194 crystallization of Emeishan mafic magmas, the metaluminous are interpreted to be derived from mixing 
of mafic magmas and crustal material (i.e. hybrid) or by partial melting of underplated mafic rocks (i.e.

196 mantle-derived) and the peralumuinous rocks are interpreted to be derived by crustal melting.

197 Therefore the peraluminous Yingpanliangzi, peralkaline Panzhihua and metaluminous Phan Si Pan 198 granitic plutons offer an opportunity to compare the results of inherited zircons from three types of

199 Emeishan silicic rocks that have different petrogenetic histories.

Neoproterozoic granitic rocks (Shellnutt et al. 2011a). The upper and lower intercepts ages of the 202 discordia appear to verify that interpretation (Fig. 6a). The pluton has enriched whole rock Sr-Nd (i.e. $\mathrm{ISr}=0.7107$ to $0.7151 ; \varepsilon \mathrm{Nd}_{(\mathrm{T})}=-3.9$ to -4.4$)$, low $\mathrm{Nb} / \mathrm{U}(<6.5)$ values and high $\mathrm{Th} / \mathrm{Nb}_{\mathrm{PM}}$ (i.e. 9.7 to

16.6) values (Shellnutt et al. 2011a). The injection of high temperature magmas into the Yangtze Block is considered to be the primary reason for crustal melting as there are mafic dykes in the same region as well as the Panzhihua layered gabbroic intrusion. The fact that the zircons from the Yingpanliangzi pluton do not form a coherent concordant age coupled with the enriched Sr-Nd isotopes suggests the Neoproterozoic Yangtze crust melted during the emplacement of the ELIP. derived by fractional crystallization of an Emeishan high-Ti basalt and directly related to the neighbouring layered oxide ore-bearing Panzhihua grabbroic intrusion (Shellnutt \& Zhou, 2007; Shellnutt \& Jahn, 2010; Shellnutt et al. 2011b). The in situ zircon U/Pb ages show there are 213 Neoproterozoic zircons that have ages of $860 \pm 7$ Ma and $854 \pm 8$ Ma with an intercept age of $848 \pm 45$ 214 Ma. In contrast to the Yingpanliangzi pluton, the Nd isotopes of the Panzhihua pluton are more 215 depleted (i.e. $\varepsilon \mathrm{Nd}_{(\mathrm{T})}=+2.2$ to +2.9 ) and trace element ratios indicative of mantle-derived rocks (i.e. $\mathrm{Th} / \mathrm{Nb}_{\mathrm{PM}}=1.0$ to $1.6 ; \mathrm{Nb} / \mathrm{U}=24.4$ to 34.0 ) rather than crust-derived rocks (Shellnutt \& Zhou 2007). 217 The geological relationships (i.e. intruded Emeishan basalt) and mineralogy (i.e. perthitic feldspar) of 
unlikely to originate from the country rock (i.e. basalt). The implication is that the Neoproterozoic 220 zircons were inherited at greater depth before the formation of Panzhihua granitic magma when the 221 parental magma was still basaltic.

Usuki et al. (2014) reported the first age dates of silicic rocks from the Phan Si Pan uplift of

\section{3}

224

225

226

227

228

229

230

231

Northern Vietnam. The rocks range in age from $\sim 252$ to $\sim 260$ Ma and are geologically correlated with inner zone of the ELIP. The metaluminous to peraluminous Phan Si Pan pluton is $\sim 256 \pm 6 \mathrm{Ma}$ and is the only silicic intrusion from northern Vietnam that was found to contain Neoproterozoic zircons. The inherited zircons range in age from $632 \mathrm{Ma}$ to $825 \mathrm{Ma}$. The Tu Le rhyolite yielded in situ zircon $\mathrm{U} / \mathrm{Pb}$ dates between $252 \pm 5 \mathrm{Ma}$ and $262 \pm 4$ Ma but contained inherited zircons with ages between $708 \mathrm{Ma}$ and 818 Ma. The petrogenetic history of the Phan Si Pan granite and Tu Le rhyolite has not been investigated thoroughly but Tran et al. (in preparation) suggest that they are derived from basaltic parental magmas. The Permian zircon $\varepsilon \mathrm{Hf}_{(\mathrm{T})}$ values of the granite and rhyolite range between +3.1 and +11.4 which is similar to Emeishan metaluminous granitic rocks that are interpreted to be derived by partial melting of underplated basaltic rocks (Xu et al. 2008; Shellnutt et al. 2009, 2011a; Usuki et al. 2014).

Granitic rocks are not the only rocks that are known to have ancient inherited zircons. Single zircons with ages of $2952 \pm 42 \mathrm{Ma}, 1927 \pm 31 \mathrm{Ma}, 1577 \pm 26,1569 \pm 29$ and $742 \pm 13 \mathrm{Ma}$ were found within the Kelang gabbroic intrusion that yielded a mean age of $256 \pm 3$ Ma (Shellnutt \& Wang 2014). The $\mathrm{Nd}$ isotopes of the Kelang gabbro are similar to many plutonic rocks in the area and have $\varepsilon \mathrm{Nd}_{(\mathrm{T})}$ values of +2.5 . The Archean to Neoproterozoic zircon ages correspond to major crust building episodes of the Yangtze Block and indicate that the parental magma interacted with rocks of that age (Qui et al. 2000; Zhang et al. 2006; Liu et al. 2008). The parental magma likely interacted with the lower most part of the crust because basement rocks of Archean age (i.e. Kongling migmatite) are thought to underlie the Proterozoic metasedimentary rocks of the Yangtze Block (Gao et al. 1999; Qiu et al. 2000; 
243 Zhang et al. 2006; Liu et al. 2008). In other words, it is unlikely that the Archean zircon was inherited 244 during final stages of emplacement because the surrounding country rocks in the area are 245 Neoproterozoic to Paleozoic.

The Neoproterozoic zircon $\mathrm{U} / \mathrm{Pb}$ ages indicate that the parental magmas of some Permian silicic and mafic rocks directly interacted with the lower crust of the Yangtze Block however the nature of the magma/country rock interaction remains uncertain. Zircon inheritance is often interpreted to be the result of late stage magma emplacement rather than source origin but the geological relationships of some of the rocks investigated indicates shallow level assimilation is unlikely. The likelihood of an inherited zircon surviving within a melt is related to its original radius, the intensity and duration of the melting event, the degree of $\mathrm{Zr}$ undersaturation in the melt, and volume of the local melt reservoir (Watson 1996). Zircons which are likely to survive temperatures $>850^{\circ} \mathrm{C}$ must be $>120 \mu \mathrm{m}$ whereas zircons $<50 \mu \mathrm{m}$ will likely be consumed at temperatures of $\sim 700^{\circ} \mathrm{C}$ therefore it is possible for original source zircons to survive melting providing they are of sufficient size (Watson 1996). Given the presence of inherited zircons in at least one known mafic intrusion, it is possible that the Neoproterozoic zircons found within some Emeishan magmatic rocks may not only be a consequence of magma/crust interaction but that, in some cases, they indicate the original source was Neoproterozoic in age.

\section{Thermodynamic modeling}

262 Equilibrium partial melt modeling was calculated using the program MELTS on three different 263 Kangdian basaltic rocks as starting compositions in order to determine if they can produce liquid 264 compositions similar to the Emeishan basalts and estimate what the most likely conditions (i.e. 265 temperature, relative oxidation state, initial water content) would have to be in order for melting to 266 occur (Ghiorso \& Sack 1995; Smith \& Asimow 2005). The initial pressure used for the partial melt 267 modeling is $1.2 \mathrm{GPa}$ (i.e. $12 \mathrm{kbar}$ ) which corresponds to the depth (i.e. $\sim 40 \mathrm{~km}$ ) of the lower crust high 
seismic velocity layer identified by $\mathrm{Xu}$ et al. (2004). The initial starting compositions are shown in

table 3 . The relative oxidation state and initial water content of each model were constrained by trial and error.

The results of the three models are shown figure 6 and can be found within the online supplementary table S1. The best models have an initial water content of $1 \mathrm{wt} \%$ and relative oxidation state of FMQ +2. In all cases, the melting curves pass through the total range of Emeishan basalt whole rock data where models EMS1 and EMS2 reproduce the high-Ti basalt compositions and model EMS3 275 reproduces the low-Ti basalt (Fig. 6). The temperature at which the models predict the composition of 276 the Emeishan basalts is first reached is at $1255^{\circ} \mathrm{C}$ for models EMS1 and EMS2 and $1275^{\circ} \mathrm{C}$ for model EM3. The amount of melting required to generate the first liquid composition equal to Emeishan basalt 278 is $\sim 75 \%$ for model EMS1, $\sim 70 \%$ for model EMS2 and $\sim 50 \%$ for model EMS3. Models EMS1 and EMS2 have distinct $\mathrm{SiO}_{2}$ gaps which form at temperatures of $1215^{\circ} \mathrm{C}$ (EMS1) and $1190^{\circ} \mathrm{C}$ (EMS2) which are due to spinel melting and reflects the higher $\mathrm{TiO}_{2}$ concentration in those models (i.e. $\mathrm{TiO}_{2}>$ $2.4 \mathrm{wt} \%$ ) in comparison with EMS3 (i.e. $\mathrm{TiO}_{2}<1.5 \mathrm{wt} \%$ ). Therefore, given the modeling parameters used, it is possible that the Kangdian basaltic rocks could produce whole rock compositions similar to the Emeishan basalts.

\section{Plausibility of a Neoproterozoic source for the Emeishan magmatic rocks}

The identification of Neoproterozoic zircons within Permian mafic and silicic plutonic rocks and the results of the partial melt modeling indicate that rocks similar in composition to the Kangdian basalts could produce the Emeishan basalts if melted. In order to evaluate the validity of this hypothesis we examine and compare the likely maximum thermal conditions of the ELIP and the isotope compositions of the Neoproterozoic rocks found within the Kangdian/Panxi rift area.

The modeled temperatures required to melt the Kangdian mafic source in order to produce the 292 Emeishan basalts is calculated to be between $1250^{\circ} \mathrm{C}$ and $1280^{\circ} \mathrm{C}$. Estimates of the eruption and mantle 
potential temperatures $\left(T_{p}\right)$ of the Emeishan ultramafic volcanic rocks were calculated using different 294 techniques by Xu et al. (2001), Zhang et al. (2006), He et al. (2010) and Ali et al. (2010). Xu et al. 295 (2001) used REE inversion and estimated the mantle potential temperatures to be $>1550^{\circ} \mathrm{C}$ whereas 296 Zhang et al. (2006) calculated mantle potential temperatures between $1630^{\circ} \mathrm{C}$ and $1690^{\circ} \mathrm{C}$. He et al. 297 (2010) and Ali et al. (2010) calculated eruption temperatures of $\sim 1440^{\circ} \mathrm{C}$ and mantle potential 298 temperatures between $\sim 1540^{\circ} \mathrm{C}$ and $\sim 1610^{\circ} \mathrm{C}$ using PRIMELT2 assuming initial $\mathrm{MgO}$ values of the 299 picrites to be $\geq 20 \%$. The wide range of mantle potential temperature may be related to differences in 300 estimates of the picrites (i.e. $\sim 1440^{\circ} \mathrm{C}$ ) are greater than the temperatures required to induce melting of the underplated mafic rocks and thus the thermal requirements of the MELTS models is plausible. The Emeishan basalts have $\varepsilon \mathrm{Nd}_{(\mathrm{T})}$ values ranging from -14.2 to +6.4 with a mean value of +0.1 $\pm 0.52 \sigma$ (Fig, 6). The $\mathrm{Sr}$, $\mathrm{Os}$ and $\mathrm{Pb}$ isotopes also show a wide range in composition (i.e. $\mathrm{I}_{\mathrm{Sr}}=0.7040$ to $0.7132 ; \gamma \mathrm{Os}=-5$ to +11 and ${ }^{206} \mathrm{~Pb} /{ }^{204} \mathrm{PbPb}_{1}=17.9$ to 19.7$)$. In comparison, albeit a smaller database,

the ultramafic volcanic rock have a higher average $\varepsilon \mathrm{Nd}_{(\mathrm{T})}$ value (i.e. $\varepsilon \mathrm{Nd}_{(\mathrm{T})}=+3.0 \pm 1.42 \sigma$ ), including the single highest reported value of +7.8 , but there is also a wide (i.e. $\varepsilon \mathrm{Nd}_{(\mathrm{T})}=-7.8$ to +7.8 ) range (Kamenetsky et al. 2012). The range in composition of the Emeishan basalts makes it difficult to distinguish between a specific source (i.e. SCLM or sublithospheric source or both) or process (i.e. crustal assimilation or mixing between an enriched component and mantle source) to explain the isotope variability (Shellnutt 2014).

The Nd-Hf isotopes of the Kangdian basalts and mafic dykes are moderately depleted (i.e. $315 \varepsilon \mathrm{Nd}_{(\mathrm{T})}=+5.0$ to $+6.0, \varepsilon \mathrm{Hf}_{(\mathrm{T})}=+7.9$ to +17.4$)$ although some differentiated basalts and trachyandesite 316 have more enriched values (i.e. $\varepsilon \mathrm{Nd}_{(\mathrm{T})}=+1.4$ to $+2.4, \varepsilon \mathrm{Hf}_{(\mathrm{T})}=+4.3$ to +8.0 ) which are attributed to 
crustal contamination ( $\mathrm{Li}$ et al. 2002, 2005; Lin et al. 2007). Zhao et al. (2008) describe

318 Neoproterozoic A- and I-type granites with $\varepsilon \mathrm{Nd}_{(\mathrm{T})}$ values of +1 and zircon $\varepsilon \mathrm{Hf}_{(\mathrm{T})}$ values of +5 to +9 319 whereas Zhao \& Zhou (2007) describe a group of slightly younger (i.e. 750 Ma) mafic intrusions in 320 southern Sichuan (near Panzhihua) that are interpreted to be derived by partial melting of a garnet321 bearing metasomatised upper mantle. The gabbros have $\mathrm{I}_{\mathrm{Sr}}$ (i.e. $\mathrm{I}_{\mathrm{Sr}}=0.7040$ to 0.7070$)$ and $\varepsilon \mathrm{Nd}_{(\mathrm{T})}($ i.e. $322 \varepsilon \mathrm{Nd}_{(\mathrm{T})}=-0.6$ to -1.7$)$ values that are indicative of a more enriched mantle source. The isotopic range of 323 the Emeishan basalts, in particular Nd isotopes, overlaps with the Neoproterozoic rocks. Furthermore 324 the Hf isotopes from the inherited zircons from NW Vietnam have $\varepsilon \mathrm{Hf}_{(\mathrm{T})}$ values are between -5.4 and $325+1.7$ which would equal $\varepsilon \mathrm{Nd}_{(\mathrm{T})}$ values of -6.3 to $-1.1($ e.g. $\varepsilon \mathrm{Hf}=1.36 \varepsilon \mathrm{Nd}+3.19)$ and fall within the 326 range of Emeishan basalt and similar to the $750 \mathrm{Ma}$ mafic intrusions. Therefore it is possible that the 327 Neoproterozoic mafic rocks, if melted, could produce the isotopic range observed within the Emeishan 328 mafic and some silicic rocks.

An alternative model for the genesis of the Emeishan basalts

331 Many models for the petrogenesis of the ELIP invoke a mantle plume model to explain the presence of 332 ultramafic rocks and voluminous flood basalts (Xu et al. 2001, 2004; Xiao et al. 2004; Song et al. 333 2004; Ali et al. 2005, 2010; Fan et al. 2008; Shellnutt 2014). Isotope enrichment and variability in 334 some trace element ratios (e.g. $\mathrm{Th} / \mathrm{Nb}_{\mathrm{PM}}, \mathrm{Nb} / \mathrm{U}$ ) of the Emeishan basalts is interpreted to be related to 335 crustal contamination with either a heterogeneous mantle source or a two mantle source (i.e. SCLM 336 plus sub-lithospheric mantle). However we suggest that it is possible that some mafic and silicic ELIP337 related magmatic rocks can be derived from Neoproterozoic lower crust rocks. The temperature 338 estimates of the ultramafic volcanic rocks is high enough to induce melting of mafic underplated 339 Neoproterozoic rocks and produce some 'second' generation magmas with a large range of isotopic 340 compositions without necessarily showing evidence of sialic crustal assimilation. Furthermore it is 
341 possible that some of the underplated Neoproterozoic rocks chemically equilibrated with older Yangtze

342 Block rocks and therefore could have more enriched isotopic compositions if melted. For example, 343 there are some Emeishan basalts that have enriched $\mathrm{Nd}$ isotope signatures (i.e. $\left.\varepsilon \mathrm{Nd}_{(\mathrm{T})}>-2\right)$ but do not 344 show strong evidence of crustal assimilation (i.e. $\mathrm{Th} / \mathrm{Nb}_{\mathrm{PM}}<2.5, \mathrm{Nb} / \mathrm{U}>25$ ) (Fig. 7).

345 The high seismic velocity layers in the lower crust of the Yangtze Block could represent pure 346 Emeishan material, pure Neoproterozoic material or a mixture of both but none of these interpretations 347 can be dismissed outright because there are no age constraints on the seismic layers. The MELTS 348 models, thermal estimates of the Emeishan ultramafic volcanic rocks and Nd-Hf isotope range of the 349 Kangdian rocks indicate that it is possible to generate derivative liquid compositions that resemble 350 Emeishan basalts and thus it is plausible that mafic Neoproterozoic rocks could be the source of some 351 Emeishan mafic or silicic rocks and that they are a consequence of lower crustal recycling indirectly 352 related to a Neoproterozoic mantle plume rather than a direct lineage to the Permian mantle plume (Fig. 353 8). Although the Permian mantle plume model is a preferred interpretation for the genesis of the 354 Emeishan ultramafic volcanic rocks and probably most basalts but the possibility that partial melting of 355 mafic Neoproterozoic lower crustal rocks could produce some of the mafic and silicic ELIP magmatic rocks cannot be easily disproved. The results of this study imply that, in some cases, mantle-plume derived large igneous provinces contribute to crustal recycling as well as juvenile crust formation.

\section{Conclusions}

360 Late Permian mafic and silicic plutonic rocks associated with the Emeishan large igneous province 361 have inherited zircons which yield Neoproterozoic U/Pb ages. The Neoproterozoic zircons indicate that 362 at least some of the ELIP magmatic rocks have evidence for direct interaction with the lower crustal 363 rocks of the Yangtze Block. The precise nature of the magma/crust interaction is uncertain as the 364 zircons may have been assimilated during emplacement or they could represent inheritance from the 
original source rocks. Thermodynamic modeling indicates that compositions similar to the Emeishan 366 flood basalts can be produced by partial melting of the Neoproterozoic Kangdian basalt at conditions 367 equal to a pressure of $1.2 \mathrm{GPa}$, water content of $\sim 1 \mathrm{wt} \%$ and $f \mathrm{O}_{2}$ of FMQ +2 . The identification of high 368 velocity seismic layers in the lower crust of the Yangtze Block, interpreted as being related to the 369 Emeishan mantle plume, may, in fact, represent underplated mafic to ultramafic rocks from the 370 Neoproterozoic magmatic event or a mixture of Neoproterozoic and Permian magmatic rocks. The 371 presence of Late Permian ultramafic volcanic rock with estimated eruption temperatures $>1400^{\circ} \mathrm{C}$ 372 would be sufficient to induce partial melting (i.e. $1250^{\circ} \mathrm{C}$ to $1280^{\circ} \mathrm{C}$ ) of the underplated mafic rocks to 373 the extent indicated by the partial melt models. Therefore, it is possible, that some Emeishan flood 374 basalts and other magmatic rocks were formed by juvenile crustal recycling induced by a high 375 temperature regime attributed to the Emeishan mantle plume.

J.G.S. would like to acknowledge the support of the National Science Council of Taiwan through grant 378 NSC 102-2628-M-003-001-MY4.

379

380

\section{References}

381 Ali, J.R., Thompson, G.M., Zhou, M.-F. \& Song, X.Y. 2005. Emeishan large igneous province, SW 382 China. Lithos, 79, 475-489.

383 Ali, J.R., Fitton, J.G. \& HerZberg, C. 2010. Emeishan large igneous province (SW China) and the 384 mantle-plume up-doming hypothesis. Journal of the Geological Society, 167, 953-959.

385 Anh, T.T., HoA, T.T., Lan, C.Y., Chung, S.-L., Lo, C.H., Wang, P.L. \& Mertzman, S. 2004. Mesozoic 386 bimodal alkaline magmatism in Tu Le basin, North Vietnam: Constraints from geochemical and 387 isotopic significances. Journal of Geology, Series B, 24, 1-9. 
388 Anh, T.V., PAng, K.N., Chung, S.-L., Lin, H.M., HoA, T.T., AnH, T.T. \& Yang, H.J. 2011. The Song Da 389 magmatic suite revisited: A petrologic, geochemical and $\mathrm{Sr}-\mathrm{Nd}$ isotopic study on picrites, flood basalts 390 and silicic volcanic rocks. Journal of Asian Earth Sciences, 42, 1341-1355.

391 Black, L.P., Kamo S.L., Allen, C.M., Aleinikoff, J.N., Davis, D.W., Korsch, R.J. \& Foudoulis, C. 392 2003a. TEMORA 1: a new zircon standard for Phanerozoic U-Pb geochronology. Chemical Geology, $393200,155-170$.

394 BLACK, L.P., KAMO, S.L., WILlIAMS, I.S., MUNDIL, R., DAVIS, D. W., KORSCH, R.J. \& 395 FOUDOULIS, C. 2003b. The application of SHRIMP to Phanerozoic geochronology; a critical 396 appraisal of four zircon standards. Chemical Geology, 200, 171-188.

397 CAmpBell, I.H. 2007. Testing the plume theory. Chemical Geology, 241, 153-176.

398 CAMPBELL, I.H. 2005. Large igneous provinces and the mantle plume hypothesis. Elements, 1, 265-269.

399 Chen, J., Yang, X., XiAO, L. \& He, Q. 2010. Coupling of basaltic magma evolution and lithospheric 400 seismic structure in the Emeishan large igneous province: MELTS modeling constraints. Lithos, 119, $401 \quad 61-74$.

402 ChUng, S.-L. \& JAHN, B.-M. 1995. Plume-lithosphere interaction in generation of the Emeishan flood 403 basalts at the Permian-Triassic boundary. Geology, 23, 889-892.

404 CHUNG, S.-L., LEE, T.Y., LO, C.H., WANG, P.L., CHEN, C.Y., NGUYEN, T.Y., HOA, T.T. \& WU, 405 G. 1997. Intraplate extension prior to continental extrusion along the Ailao Shan-Red River shear zone. 406 Geology, 25, 311-314.

407 Claoue-Long, J.C., Compston, W., Roberts, J. \& Fanning, M. 1995. Two Carboniferous ages: a 408 comparison of SHRIMP zircon dating with conventional zircon ages and ${ }^{40} \mathrm{Ar} /{ }^{39} \mathrm{Ar}$ analysis. 409 Geochronology Time Scales and Global Stratigraphic Correlation, SEPM Special Publication, 54, 341021. 
411 Compston, W., Williams, I.S. \& MeYer, C. 1984. U-Pb geochronology of zircons from Lunar breccia 41273217 using a sensitive high mass-resolution ion microprobe. Journal of Geophysical Research, 89, $413 \quad 525-534$.

414 DaO, D.T., \& HuYnH, T. 1995. Magmatic formations of Vietnam. Vietnamese Geological Survey (in 415 Vietnamese).

416 Dovjikov A.E. 1965. Geology of North Vietnam. Publishing House Sciences and Technics, 668 pp. (in 417 Vietnamese).

418 FAn, W., Zhang, C., Wang, Y., GuO, F. \& Peng, T. 2008. Geochronology and geochemistry of Permian 419 basalts in western Guangxi Province, southwest China: evidence for plume-lithosphere interaction. 420 Lithos, 102, 218-236.

421 GaO, S., Ling, W.L., QiU, Y.M., Zhou, L., Hartmann, G., Simon, K. 1999. Contrasting geochemical and 422 Sm-Nd isotopic compositions of Archean metasediments from the Kongling high-grade terrane of the 423 Yangtze craton: evidence for cratonic evolution and redistribution of REE during crustal anatomies. 424 Geochimica et Cosmochimica Acta, 63, 2071-2088.

425 Ghiorso, M.S. \& SACK, R.O. 1995. Chemical mass transfer in magmatic processes IV. A revised and 426 internally consistent thermodynamic model for the interpolation and extrapolation of liquid-solid 427 equilibria in magmatic systems at elevated temperatures and pressures. Contributions to Mineralogy 428 and Petrology, 119, 197-212.

429 Griffin, W.L., Pearson, N.J., Belousova, E.A., Jackson, S.E., O'Reilly, S.Y., van Achterberg, E. \& 430 SHEE, S.R. 2000. The Hf-isotope composition of cratonic mantle: LAM-MC-ICPMS analysis of zircon 431 megacrysts in kimberlites. Geochimica et Cosmochimica Acta, 64, 133-147.

432 Griffin, W.L., Belousova, E.A., Shee, S.R., Pearson, N.J. \& O'Reilly, S.Y. 2004. Archean crustal 433 evolution in the northern Yilgarn Craton: U-Pb and Hf-isotope evidence from detrital zircons. 434 Precambrian Research, 131, 231-282. 
435 Hanski, E., Walker, R.J., Huhma, H., Polyakov, G.V., Balykin, P.A., HoA, T.T. \& Phuong, N.T. 436 2004. Origin of the Permian-Triassic komatiites, northwestern Vietnam. Contributions to Mineralogy 437 and Petrology, 147, 453-469.

438 He, B., Xu, Y.-G., Chung, S.-L., XiaO, L. \& Wang, Y. 2003. Sedimentary evidence for a rapid, 439 kilometer-scale crustal doming prior to the eruption of the Emeishan flood basalts. Earth and Planetary $440 \quad$ Science Letters, 213, 391-405.

441 He, Q., Xiao, L., Balta, B., Gao, R. \& Chen, J. 2010. Variety and complexity of the Late-Permian 442 Emeishan basalts: reappraisal of plume-lithosphere interaction processes. Lithos, 119, 91-107.

443 Hou, Z.Q., LU, J.R. \& LiN, S.Z. 2006. Heterogeneity of a plume axis: bulk-rock geochemical evidence 444 from picrites and basalts in the Emei large igneous province, southwest China. International Geology 445 Review, 48, 1087-1112.

446 Kamenetsky, V.S., Chung, S.-L., Kamenetsky, M.B. \& Kuzmin, D.V. 2012. Picrites from the 447 Emeishan large igneous province, SW China: a compositional continuum in primitive magmas and 448 their respective mantle sources. Journal of Petrology, 53, 2095-2113.

449 Lan, C.Y., Usuki, T., WANG, K.L., Yui, T.F., OKAmoto, K., LeE, Y.H., HiRATA, T., Kon, Y., ORIHASHI, 450 Y., Liou, J.G. \& LEE, C.S. 2009. Detrital zircon evidence for the antiquity of Taiwan. Geosciences 451 Journal, 13, 233-243.

452 Lan, C.Y., Chung, S.L., Lo, C.H., LeE, T.Y., Wang, P.L., Li, H. \& Dinh, V.T. 2001. First evidence for 453 Archean continental crust in northern Vietnam and its implications for crustal and tectonic evolution in 454 Southeast Asia. Geology, 29, 219-222.

455 Leloup, P.H., Lacassin, R., TApponnier, P., SchÄrer, U., Zhong, D., LiU, X., Zhang, L.S., Ji, S.C. \& 456 Phan, T.T. 1995. The Ailao Shan-Red River shear zone (Yunnan, China), Tertiary transform boundary 457 of Indochina. Tectonophysics, 251, 3-84. 
458 Li, X.-H., Li, Z.-X., Sinclair, J.A., LI, W.-X. \& CARTER, G. 2006. Revisiting the "Yanbian Terrane": 459 implications for Neoproterozoic tectonic evolution of the western Yangtze block, South China. 460 Precambrian Research, 151, 14-30.

461 Li, X., QI, C., LiU, Y., Liang, X., TU, X., XIE, L. \& YANG, Y. 2005. Petrogenesis of the Neoproterozoic 462 bimodal volcanic rocks along the western margin of the Yangtze block: new constraints from Hf 463 isotopes and Fe/Mn ratios. Chinese Science Bulletin, 50, 2481-2486.

464 Li, X.-H., LI, Z.-X., ZHOU, H., LiU, Y. \& KINNY, P.D. 2002. U-Pb zircon geochronology, geochemistry 465 and Nd isotopic study of Neoproterozoic bimodal volcanic rocks in the Kangdian rift of South China: 466 implications for the initial rifting of Rodinia. Precambrian Research, 113, 135-154.

467 Li, Z.X., LI, X.H., KinNY, P.D. \& WANG, J. 1999. The breakup of Rodinia: did it start with a mantle plume 468 beneath South China? Earth and Planetary Science Letters, 173, 171-181.

469 LIN, G., LI, X. \& LI, W. 2007. SHRIMP U-Pb zircon age, geochemistry and Nd-Hf isotope of 470 Neoproterozoic mafic dyke swarms in western Sichuan: petrogenesis and tectonic significance. Science 471 in China: Earth Sciences, 50, 1-16.

472 Ma, Y.X., Zhou, R.S., Wan, Y.W., LiU, F., QIU, Y.D. \& Wang H.F. 1999. Geology of Panzhihua City 473 area (Map G-47-60-A). Chengdu University of Science and Technology, 1: 50000.

474 NAM, T.N. 2001. Ages of the Ca Vinh and Xom Giau complexes: First reliable evidence from SHRIMP $475 \mathrm{U}-\mathrm{Pb}$ zircon dating. Geology Series A, 262, 1-11 (in Vietnamese).

476 Nam, T.N. Toruimi M., Sano Y., Terada K. \& Thang T.T. 2003. 2.9, 2.36 and 1.96 Ga zircon in 477 orthogneiss south of Red River shear zone in Vietnam: evidence from SHRIMP U-Pb dating and 478 tectonothermal implications. Journal of Asian Earth Sciences, 21, 743-753.

479 Qiu, Y.M., Gao, S., McNaughton, N.J., Groves, D.I., Ling, W. 2000. First evidence of > 3.2 Ga 480 continental crust in the Yangtze craton of south China and its implications for Archean crustal 481 evolution and Phanerozoic tectonics. Geology, 28, 11-14. 
482 RudniCK, R.L. \& GaO, S., 2003. Composition of the continental crust. In: RudniCK, R.L. (ed) The Crust. 483 Treatise on Geochemistry, 3, 1-64.

484 Shellnutt, J.G. 2014. The Emeishan large igneous province: a synthesis. Geoscience Frontiers, 5, 369485394.

486 ShellnutT, J.G. \& WAng, K.-L. 2014. An ultramafic parental magma for a low Si-Al, high Ti-Fe gabbro 487 in the Panxi region of the Emeishan large igneous province, SW China. Journal of Asian Earth 488 Sciences, 79, 329-344.

489 Shellnutt, J.G., Denyszyn, S. \& Mundil, R. 2012. Precise age determination of mafic and felsic 490 intrusive rocks from the Permian Emeishan large igneous province (SW China). Gondwana Research, $491 \quad 22,118-126$.

492 ShellnutT, J.G. \& JAHn, B.-M. 2011. Origin of Late Permian Emeishan basaltic rocks from the Panxi 493 region (SW China): implications for the Ti-classification and spatial-compositional distribution of the 494 Emeishan basalts. Journal of Volcanology and Geothermal Research, 199, 85-95.

495 ShellnutT, J.G., JAhn, B.-M. \& Zhou, M.-F. 2011a. Crustal-derived granites in the Panzhihua region, 496 SW China: implications for felsic magmatism in the Emeishan large igneous province. Lithos, 123, $497 \quad 145-157$.

498 Shellnutt, J.G., WAng, K.-L., Zellmer, G.F., Iizuka, Y., Jahn, B.-M., Pang, K.-N., Qi, L. \& Zhou, 499 M.-F. 2011b. Three Fe-Ti oxide ore-bearing gabbro-granitoid complexes in the Panxi region of the 500 Emeishan large igneous province, SW China. American Journal of Science, 311, 773-812.

501 ShellnutT, J.G. \& Jahn, B.-M. 2010. Formation of the Late Permian Panzhihua plutonic-hypabyssal502 volcanic igneous complex: implications for the genesis of Fe-Ti oxide deposits and A-type granites of 503 SW China. Earth and Planetary Science Letters, 289, 509-519.

504 ShellnutT, J.G. \& ZHOU, M.-F. 2007. Permian peralkaline, peraluminous and metaluminous A-type 505 granites in the Panxi district, SW China: their relationship to the Emeishan mantle plume. Chemical 506 Geology, 243, 286-316. 
507 Smith, P.M. \& Asimow, P.D. 2005. Adiabat_1ph: a new public front-end to the MELTS, pMELTS, and 508 pHMELTS models. Geochemistry, Geophysics Geosytems, 6, Q02004, doi: 10.1029/2004GC000816. 509 Söderlund, U., PAtchett, P.J., Vervoort, J.D. \& IsAChsen, C.E. 2004. The ${ }^{176}$ Lu decay constant 510 determined by $\mathrm{Lu}-\mathrm{Hf}$ and $\mathrm{U}-\mathrm{Pb}$ isotope systematics of Precambrian mafic intrusions. Earth and $511 \quad$ Planetary Science Letters, 219, 311-324.

512 Song, X.Y., QI, H.-W., Robinson, P.T., Zhou, M.-F., CAO, Z.-M. \& Chen, L.-M. 2008a. Melting of the 513 subcontinental lithospheric mantle by the Emeishan mantle plume; evidence from the basal alkaline 514 basalts in Dongchuan, Yunnan, southwestern China. Lithos, 100, 93-111.

515 Song, X.-Y., Zhou, M.-F., TAO, Y. \& XiAO, J.-F. 2008b. Controls on the metal compositions of magmatic 516 sulfide deposits in the Emeishan large igneous province, SW China. Chemical Geology, 253, 38-49.

517 Song, X.-Y., Zhou, M.-F., CAO, Z.-M. \& Robinson, P. 2004. Late Permian rifting of the South China 518 craton caused by the Emeishan mantle plume? Journal of Geological Society, 161, 773-781.

519 Song, X.-Y., Zhou, M.-F., Hou, Z.-Q., CAO, Z.-M., WANG, Y.-L. \& LI, Y. 2001. Geochemical constraints 520 on the mantle source of the upper Permian Emeishan continental flood basalts, southwestern China. 521 International Geology Review, 43, 213-225.

522 Tapponnier P., Lacassin R., Leloup, P.H., Scharer, U., Zhong, D., LiU X., Ji, S., Zhang, L. \& Zhong 523 J. 1990. The Ailao Shan/Red River metamorphic belt: Tertiary left-lateral shear between Indochina and 524 South China. Nature, 343, 432-437.

525 Tran, D.L. \& Nguyen, X.B. 1988. Geological Map of Vietnam, scale 1: 500.000. Vietnam General 526 Department of Geology and Mining.

527 Tran, V.T. 1977. Geology of Vietnam. North part. Explanation to geological map of Vietnam, North 528 part, scale 1: 1,000,000. Publishing House Sciences and Technics, 355 pp. (in Vietnamese).

529 Usuki, T., Lan, C.-Y., HoA, T.T., Dung, P.T., Wang, K.-L., Shellnutt, J.G. \& Chung, S.-L. 2014. 530 Zircon $\mathrm{U}-\mathrm{Pb}$ ages and $\mathrm{Hf}$ isotopic compositions of alkaline silicic magmatic rocks in the Phan Si Pan- 
531 Tu Le region, northern Vietnam: identification of a displacement western extension of the Emeishan 532 large igneous province. Journal of Asian Earth Sciences, doi: 10.1016/j.jseaes.2014.10.016.

533 Wang, C.Y., ZHOU, M.-F. \& QI, L. 2011. Chalcophile element geochemistry and petrogenesis of high-Ti 534 and low-Ti magmas in the Permian Emeishan large igneous province, SW China. Contributions to 535 Mineralogy and Petrology, 161, 237-254.

536 Wang, C.Y., ZhOU, M.F. \& QI, L. 2007. Permian flood basalts and mafic intrusions in the Jinping (SW 537 China)-Song Da (northern Vietnam) district: Mantle sources, crustal contamination and sulfide 538 segregation. Chemical Geology, 243, 317-343.

539 Wang, Q., Wyman, D.A., Li, Z.-X., BaO, Z.-W., ZhaO, Z.-H., Wang, Y.-X., Jian, P., Yang, Y.-H. \& 540 CHEN, L.-L. 2010. Petrology, geochronology and geochemistry of ca. 780 Ma A-type granites in South 541 China: petrogenesis and implications for crustal growth during the breakup of the supercontinent 542 Rodinia. Precambrian Research, 178, 185-208.

543 Wang, X.-C., LI, X.-H., LI, W.-X. \& LI, Z.-X. 2009. Variable involvements of mantle plumes in the 544 genesis of mid-Neoproterozoic basaltic rocks in South China: a review. Gondwana Research, 15, 381545395.

546 Watson, E.B. 1996. Dissolution, growth and survival of zircons during crustal fusion: kinetic principals, 547 geological models and implications for isotopic inheritance. Transactions of the Royal Society of 548 Edinburgh, 87, 43-56.

549 Wiedenbeck, M., Alle, P., Corfu, F., Griffin, W.L., Meier, M., Oberli, F., von Quadt, A., Roddick, 550 J.C. \& SPIEGEL, W. 1995. Three natural zircon standards for U-Th-Pb, Lu-Hf, trace element and REE 551 analyses. Geostandards and Geoanalytical Research, 19, 1-23.

552 XiaO, L., Xu, Y.G., MeI, H.J., Zheng, Y.F., He, B. \& PiRAjno, F. 2004. Distinct mantle sources of low-Ti 553 and high-Ti basalts from the western Emeishan large igneous province, SW China: implications for 554 plume-lithosphere interaction. Earth and Planetary Science Letters, 228, 525-546. 
555 XU, Y.-G. \& HE, B. 2007. Thick and high velocity crust in Emeishan large igneous province, SW China:

556 Evidence for crustal growth by magmatic underplating/intraplating. In: Foulger, G.R. \& Jurdy, D.M. 557 (eds) Plates, Plumes and Planetary Processes. Geological Society of America Special Paper, 430, 841558858.

559 Xu, Y.G., He, B., Chung, S.L., MenzIES, M. \& Frey, F.A. 2004. Geologic, geochemical, and geophysical 560 consequences of plume involvement in the Emeishan flood-basalt province. Geology, 32, 917-920.

561 Xu, Y., Chung, S.L., Jahn, B.M. \& WU, G. 2001. Petrologic and geochemical constraints on the 562 petrogenesis of Permian-Triassic Emeishan flood basalts in southwestern China. Lithos, 58, 145-168.

563 Zhang, Z., Mahoney, J.J., Mao, J. \& Wang, F. 2006. Geochemistry of Picritic and Associated Basalt 564 Flows of the Western Emeishan Flood Basalt Province, China. Journal of Petrology, 47, 1997-2019.

565 ZHAO, J.-H. \& ZHOU, M.-F. 2007. Geochemistry of Neoproterozoic mafic intrusions in the Panzhihua 566 district (Sichuan Province, SW China): Implications for subduction-related metasomatism in the upper 567 mantle. Precambrian Research, 152, 27-47.

568 ZhaO, X.-F., ZhOU, M.-F., LI, J.-W. \& WU, F.-Y. 2008. Association of Neoproterozoic A- and I-type 569 granites in South China: implications for generation of A-type granites in a subduction-related 570 environment. Chemical Geology, 257, 1-15.

571 Zhou, J., Wang, X., QIU, J. \& GaO, J. 2004. Geochemistry of Meso- and Neoproterozoic mafic572 ultramafic rocks from northern Guangxi, China: arc or plume magmatism. Geochemical Journal, 38, 573 139-152.

574 Zhou, M.-F., Arndt, N.T., Malpas, J., Wang, C.Y. \& Kennedy, A.K. 2008. Two magma series and 575 associated ore deposit types in the Permian Emeishan large igneous province, SW China. Lithos, 103, $576 \quad 352-368$.

577 Zhou, M.-F., YAN, D.P., KenNEDY, A.K. LI, Y. \& DING, J. 2002a. SHRIMP U-Pb zircon geochronological 578 and geochemical evidence for Neoproterozoic arc-magmatism along the western margin of the Yangtze 579 block, South China. Earth and Planetary Science Letters, 196, 51-67. 
580 Zhou, M.-F., Kennedy, A.K., Sun, M., Malpas, J. \& Lesher, C.M. 2002a. Neo-proterozoic arc-related

581 mafic intrusions along the northern margin of South China: implications for accretion of Rodinia. 582 Journal of Geology, 110, 611-618.

583

584

585 Figure Captions

586 Fig. 1. (a) Distribution of the Emeishan large igneous province showing the concentric zones (dashed red 587 lines) and locations of the Panxi intrusions and Song Da intrusion. (b) Seismic P-wave velocity (km/s) 588 structure of the lower crust and upper mantle beneath the western Yangtze Block from Lijiang (A) to 589 Zhehai (B) (modified from Xu et al. 2004).

590 Fig. 2. Simplified geological map of NW Vietnam (modified from Usuki et al., 2014).

591 Fig. 3. Sample geological map of the Panzhihua region showing the locations of samples GS03-065 592 (Yingpanliangzi granite) and GS03-010 (Panzhihua granite). Modified from Ma et al. (1999).

593 Fig. 4. Cathodoluminescence images of (a) one zircon showing highly complex internal structure. Zone 1 594 is a low $\mathrm{U}$ region whereas zone 2 is a high $\mathrm{U}$ region. (b) Multiple growth zones with a low $\mathrm{U}$ core.

595 Fig. 5. Concordia diagrams of the (a) Yingpanliangzi pluton and the (b) Panzhihua peralkaline granite.

596 Fig. 6. Results of equilibrium partial melt modeling of the Kangdian mafic rocks. All models rocks were 597 calculated at a relative oxidation state of FMQ +2, pressure of $1.2 \mathrm{GPa}$ and water content of $1 \mathrm{wt} \%$. 598 Source rock compositions can be found in table 3. All modeled results and Emeishan basalt data 599 normalized to 100\%. Emeishan basalt data compiled in Shellnutt \& Jahn (2011).

600 Fig. 7. (a) $\varepsilon \mathrm{Nd}_{(\mathrm{T})}$ vs. $\mathrm{Nb} / \mathrm{U}$ ratio of the high-Ti and low-Ti Emeishan flood basalts, Emeishan ultramafic 601 volcanic rocks and Neoproterozoic mafic rocks. (b) $\varepsilon N d_{(\mathrm{T})} \mathrm{vs}$. $\mathrm{Th} / \mathrm{Nb}_{\mathrm{PM}}$ ratio of the high- $\mathrm{Ti}$ and low-Ti 602 Emeishan flood basalts, Emeishan ultramafic volcanic rocks and Neoproterozoic mafic rocks. The $603 \mathrm{Th} / \mathrm{Nb}$ ratio is normalized to primitive mantle of Sun \& McDonough (1989). The values of average 
604 lower crust and upper crust from Rudnick and Gao (2003). Emeishan compiled in Shellnutt \& Jahn 605 (2011) and Kamenetsky et al. (2012). Data for the Kangdian basalts and mafic intrusions from Li et al. 606 (2002, 2006, 2007) and Zhao \& Zhou (2007).

607 Fig. 8. Conceptual model of the lower crust origin of some Emeishan magmatic rocks. 


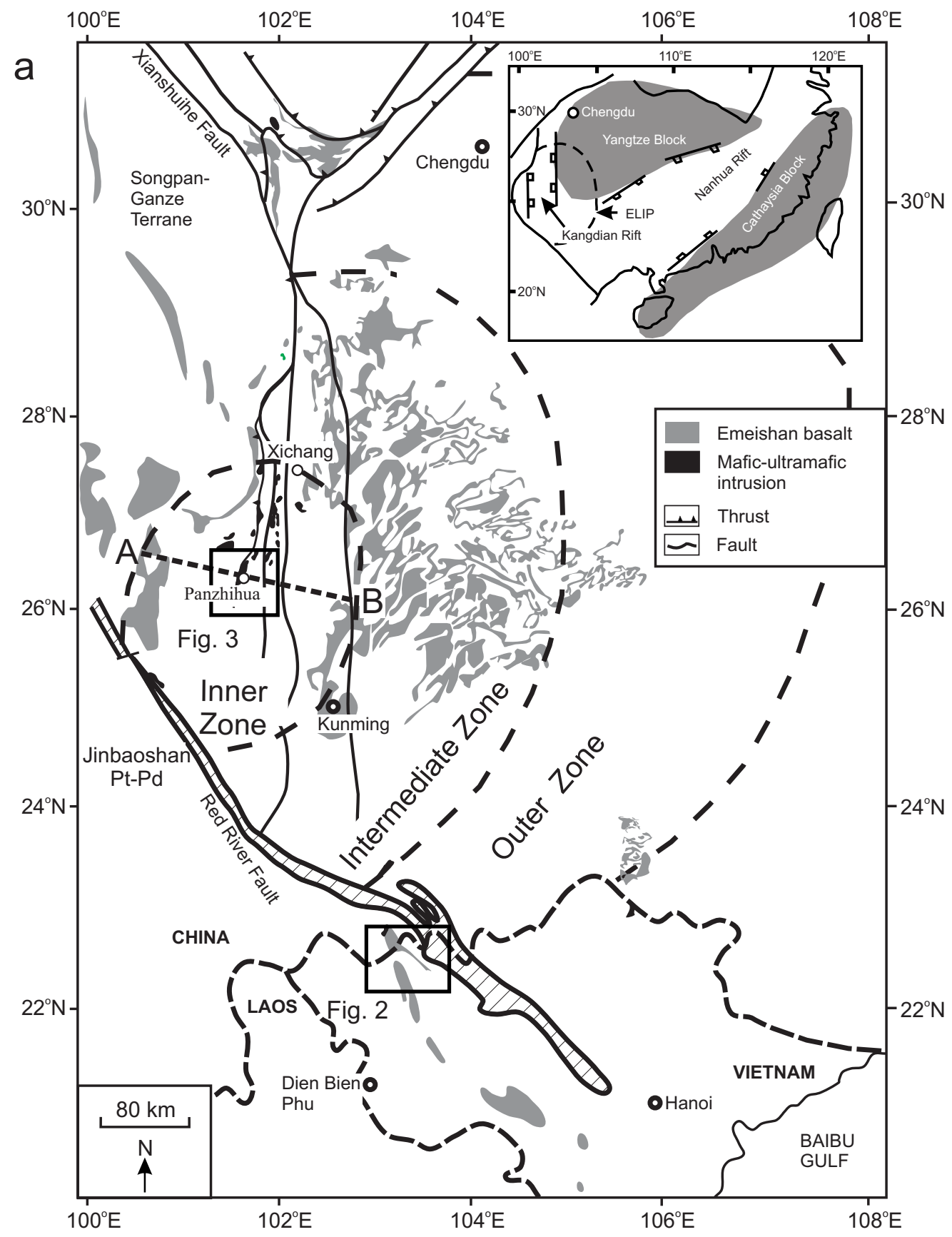

b A

B

Lijiang

Zhehai

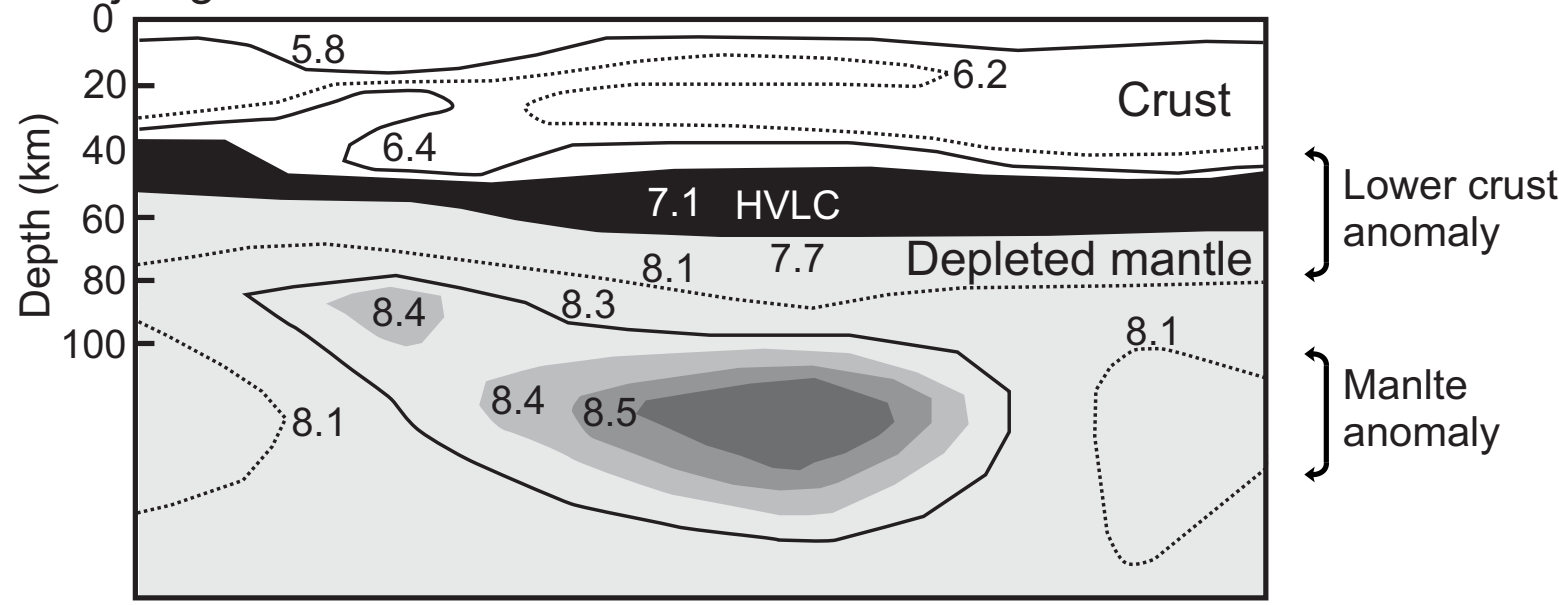




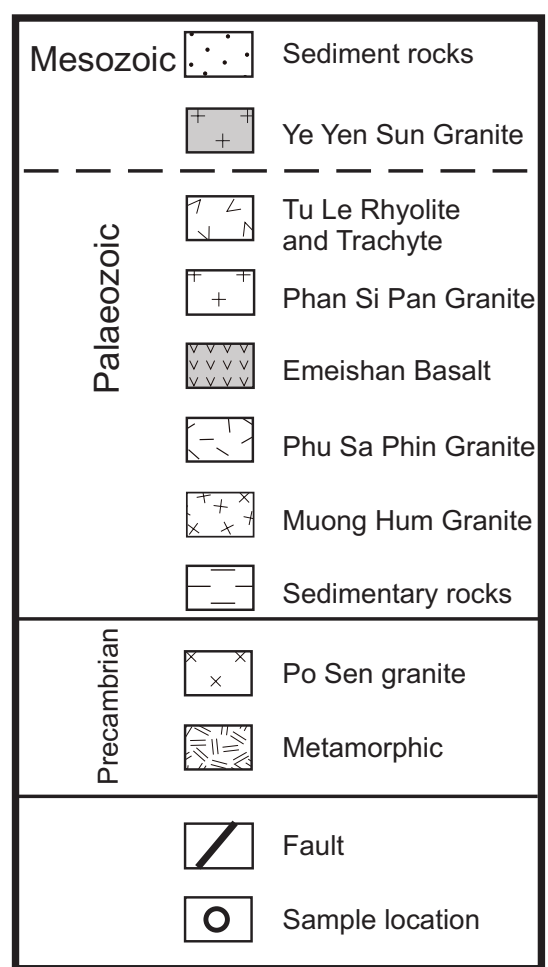

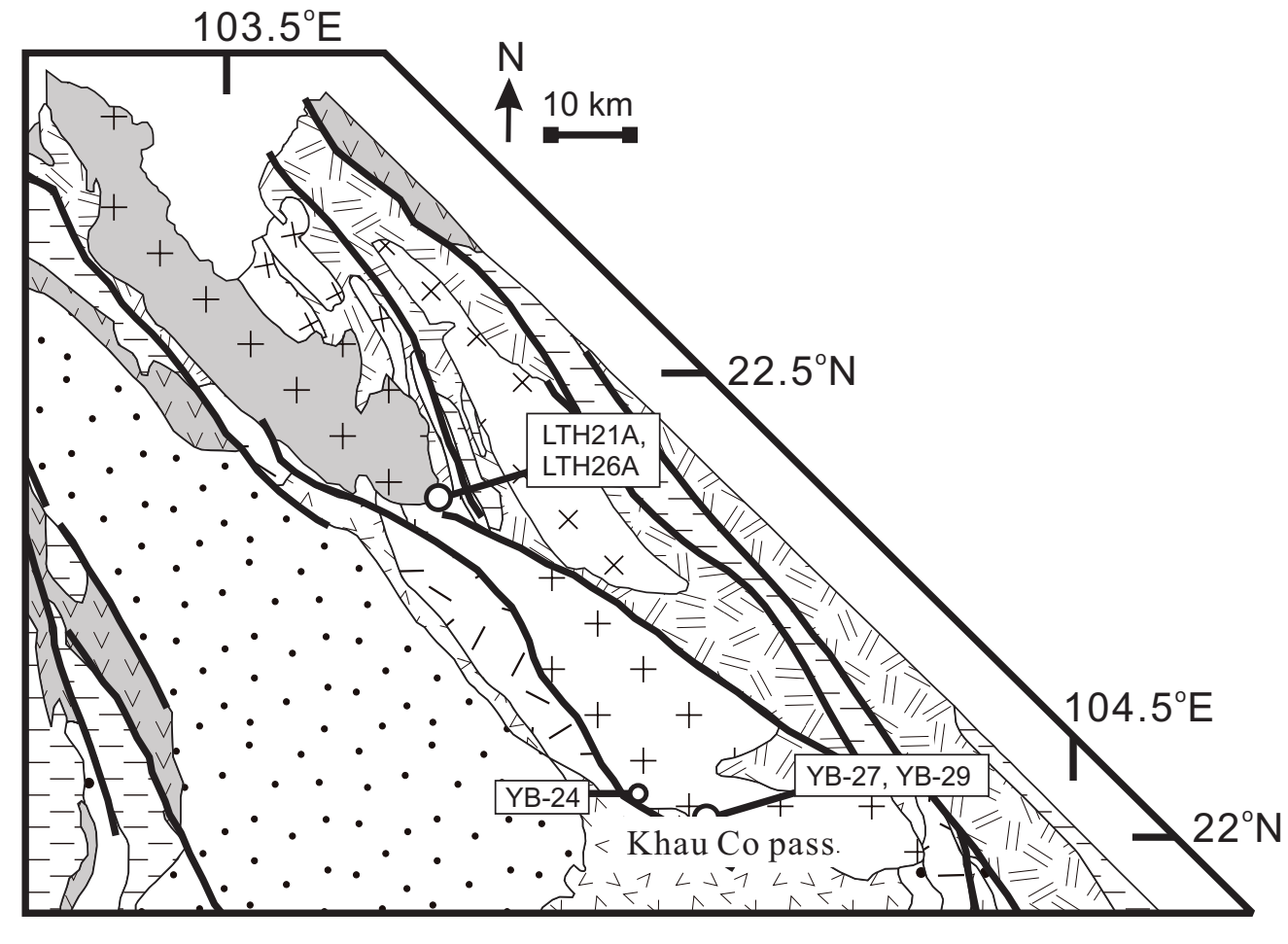



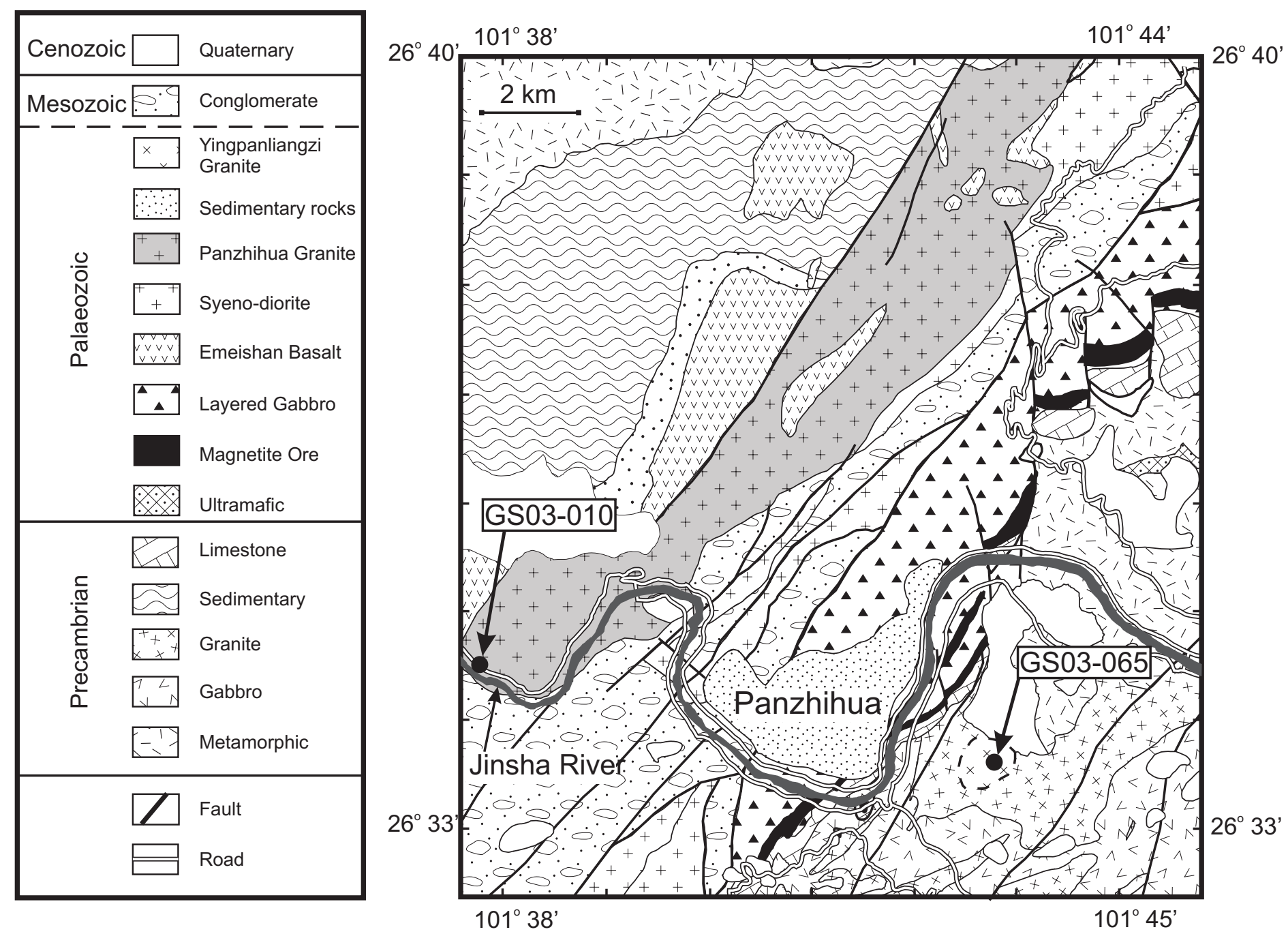


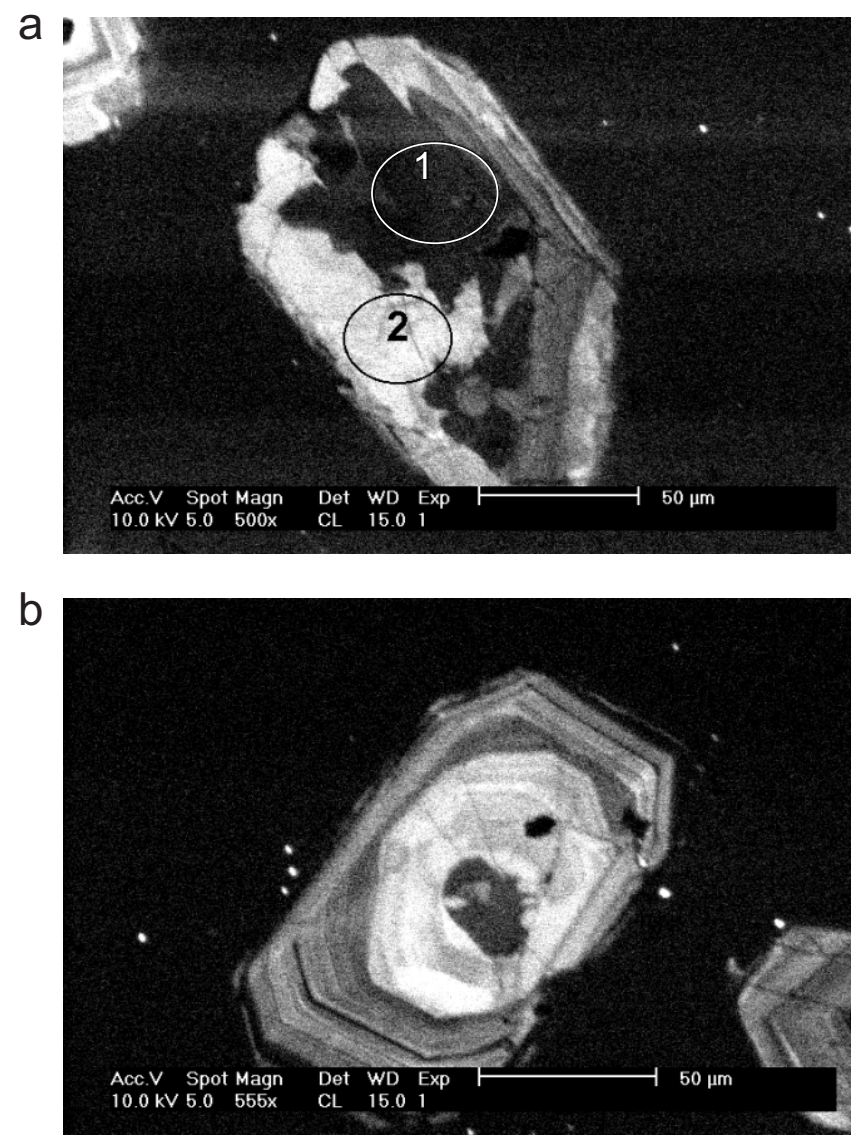



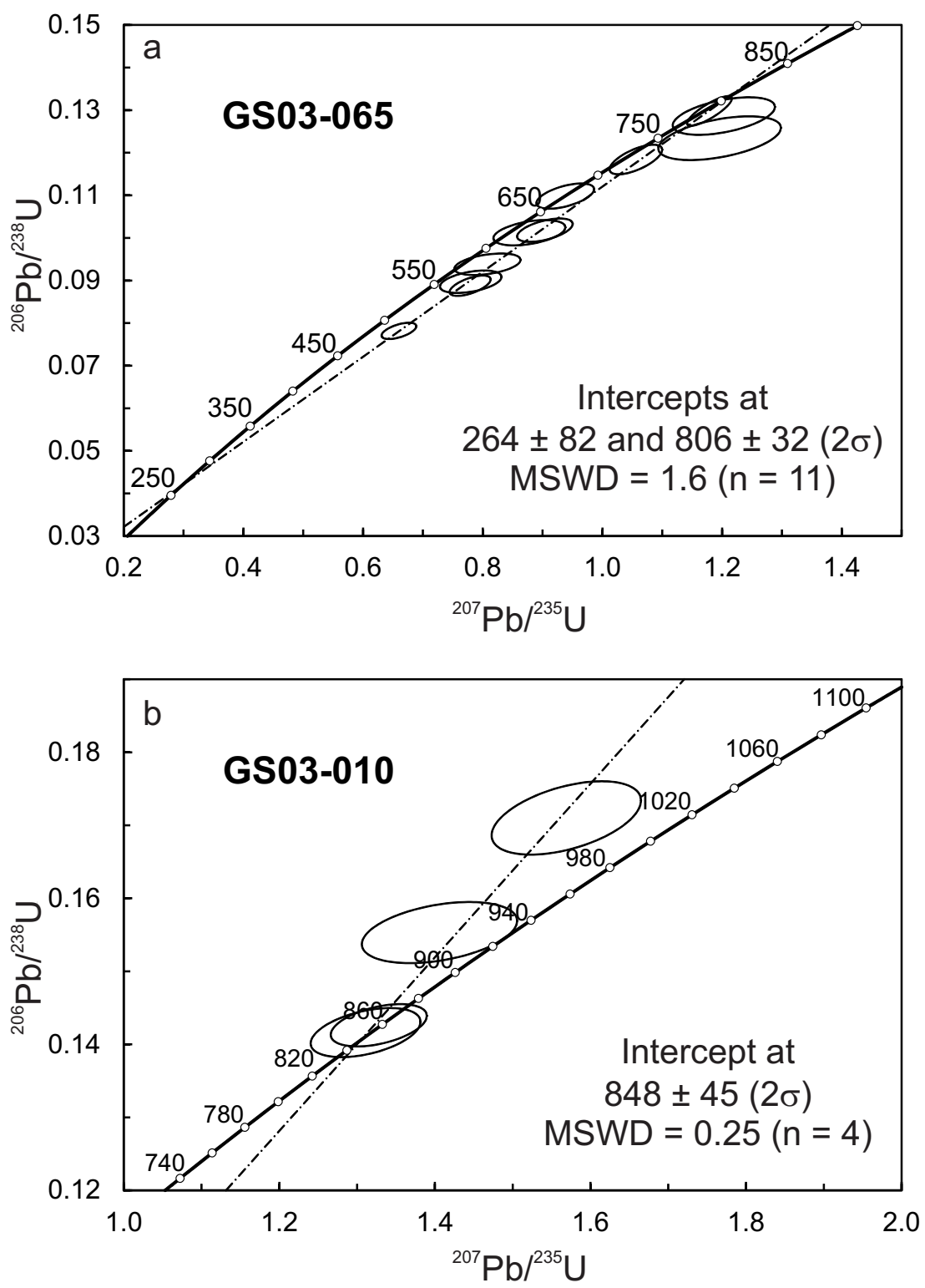

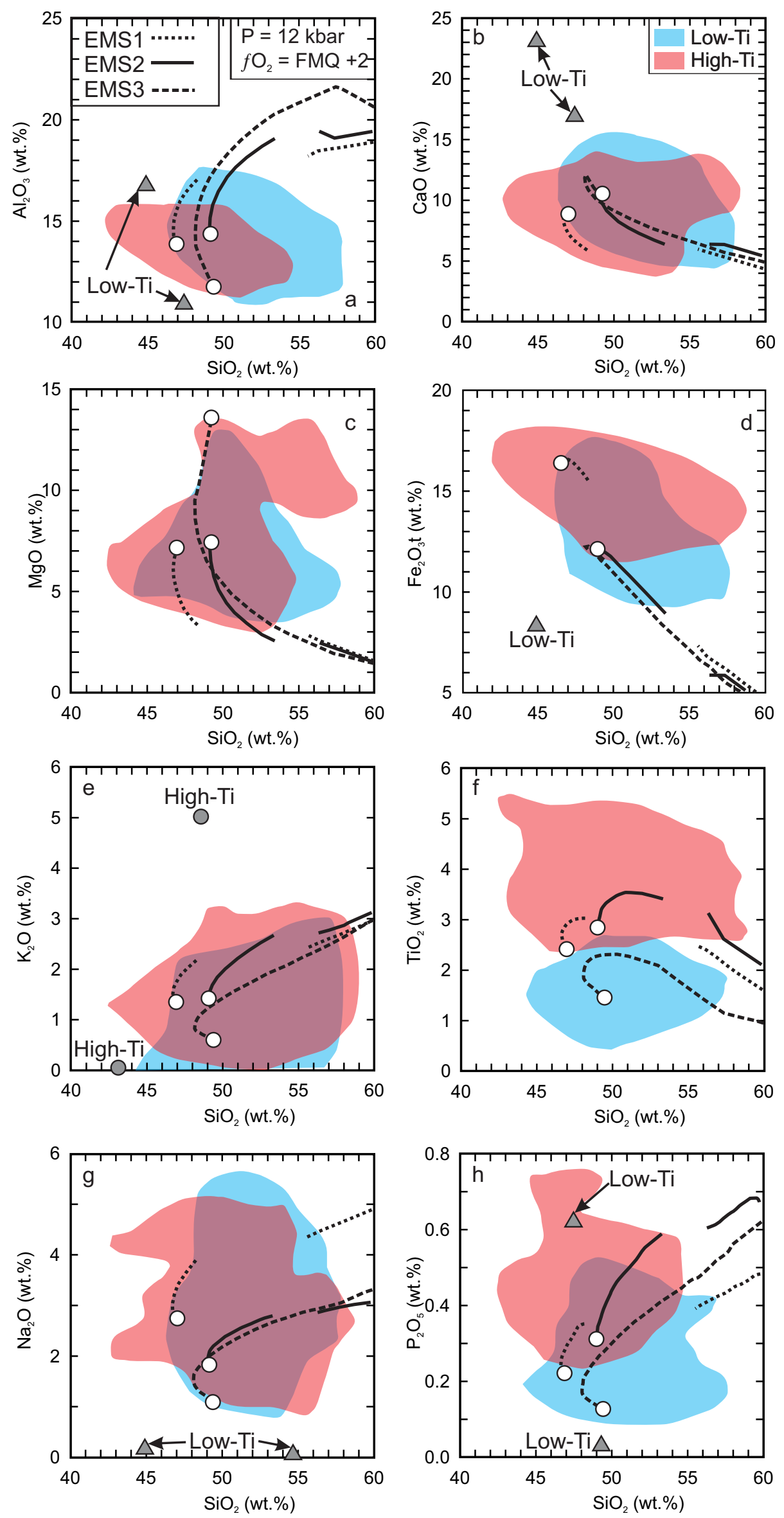

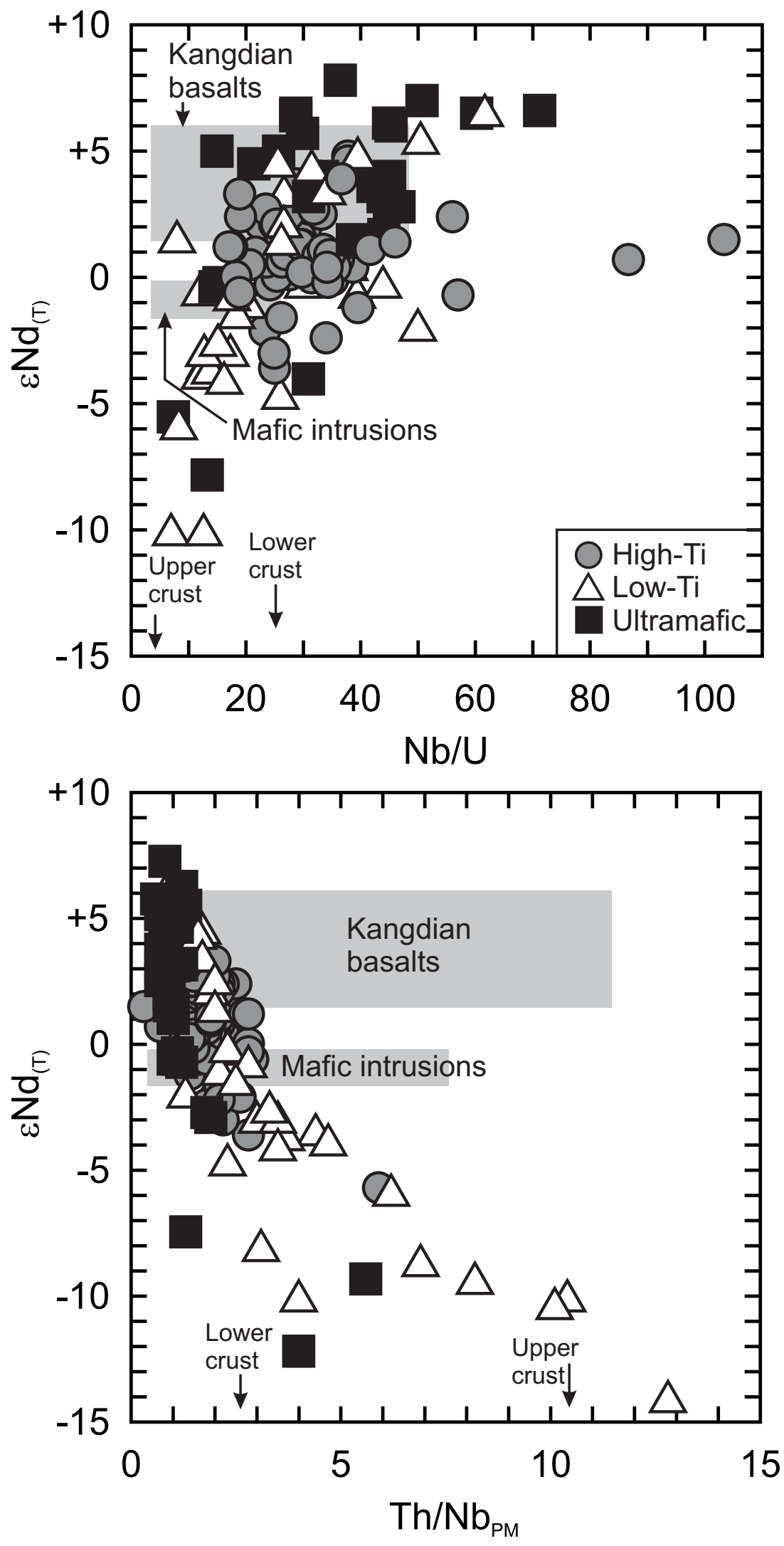


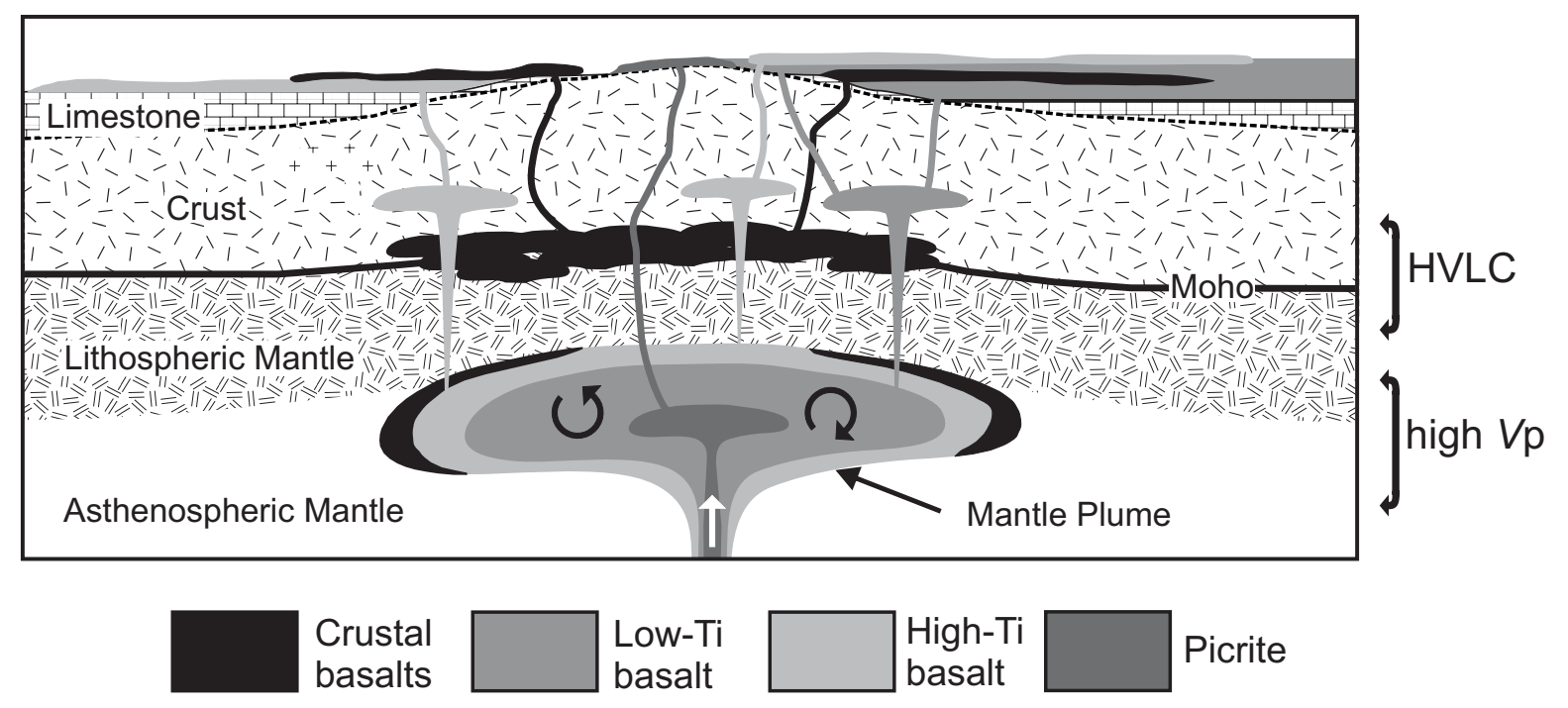


Table 1. SHRIMP U-Pb ages of inherited zircons from the Panzhihua and Yingpanliangzi granitic plutons

\begin{tabular}{|c|c|c|c|c|c|c|c|c|c|c|c|c|}
\hline Sample & $\begin{array}{c}\mathrm{U} \\
(\mathrm{ppm})\end{array}$ & $\begin{array}{c}\text { Th } \\
(\mathrm{ppm})\end{array}$ & $\mathrm{Th} / \mathrm{U}$ & ${ }^{207} \mathrm{~Pb} /{ }^{206} \mathrm{~Pb}$ & $\pm 1 \sigma$ & ${ }^{207} \mathrm{~Pb} /{ }^{235} \mathrm{U}$ & $\pm 1 \sigma$ & ${ }^{206} \mathrm{~Pb} /{ }^{238} \mathrm{U}$ & $\pm 1 \sigma$ & $\begin{array}{l}\text { error } \\
\text { corr. }\end{array}$ & $\begin{array}{l}{ }^{206} \mathrm{~Pb} /{ }^{238} \mathrm{U} \\
(\mathrm{Ma} \pm 1 \sigma)\end{array}$ & $\begin{array}{c}{ }^{207} \mathrm{~Pb} /{ }^{206} \mathrm{~Pb} \\
(\mathrm{Ma} \pm 1 \sigma)\end{array}$ \\
\hline \multicolumn{13}{|l|}{ Panzhihua } \\
\hline GS03-010-2 & 489 & 266 & 0.56 & 0.0675 & 0.0011 & 1.3280 & 0.0252 & 0.1426 & 0.0012 & 0.447 & $860 \pm 7$ & $854 \pm 34$ \\
\hline GS03-010-3 & 262 & 267 & 1.05 & 0.0657 & 0.0018 & 1.4060 & 0.0408 & 0.1553 & 0.0017 & 0.383 & $930 \pm 10$ & $797 \pm 57$ \\
\hline GS03-010-4 & 515 & 26 & 0.05 & 0.0666 & 0.0015 & 1.5690 & 0.0392 & 0.1710 & 0.0021 & 0.476 & $1018 \pm 11$ & $824 \pm 46$ \\
\hline GS03-010-6 & 435 & 175 & 0.42 & 0.0672 & 0.0013 & 1.3110 & 0.0288 & 0.1416 & 0.0014 & 0.440 & $854 \pm 8$ & $843 \pm 41$ \\
\hline \multicolumn{13}{|l|}{ Yingpanliangzi } \\
\hline GS03-065-1 & 176 & 114 & 0.67 & 0.0631 & 0.0016 & 0.7800 & 0.0211 & 0.0897 & 0.0011 & 0.432 & $554 \pm 6$ & $711 \pm 53$ \\
\hline GS03-065-4 & 233 & 271 & 1.20 & 0.0620 & 0.0011 & 0.9380 & 0.0197 & 0.1098 & 0.0012 & 0.551 & $671 \pm 7$ & $674 \pm 37$ \\
\hline GS03-065-5 & 300 & 253 & 0.87 & 0.0658 & 0.0005 & 1.1790 & 0.0153 & 0.1298 & 0.0014 & 0.837 & $787 \pm 8$ & $801 \pm 15$ \\
\hline GS03-065-6 & 236 & 133 & 0.58 & 0.0645 & 0.0012 & 0.9040 & 0.0190 & 0.1018 & 0.0011 & 0.541 & $625 \pm 7$ & $757 \pm 37$ \\
\hline GS03-065-7 & 391 & 226 & 0.60 & 0.0637 & 0.0009 & 0.7790 & 0.0140 & 0.0888 & 0.0010 & 0.621 & $548 \pm 6$ & $731 \pm 30$ \\
\hline GS03-065-8 & 903 & 949 & 1.09 & 0.0613 & 0.0009 & 0.6600 & 0.0119 & 0.0782 & 0.0008 & 0.575 & $485 \pm 5$ & $649 \pm 32$ \\
\hline GS03-065-9 & 36 & 23 & 0.66 & 0.0703 & 0.0022 & 1.1960 & 0.0419 & 0.1234 & 0.0021 & 0.477 & $750 \pm 12$ & $937 \pm 63$ \\
\hline GS03-065-10 & 62 & 46 & 0.77 & 0.0678 & 0.0017 & 1.2030 & 0.0349 & 0.1286 & 0.0018 & 0.491 & $780 \pm 10$ & $863 \pm 53$ \\
\hline GS03-065-11 & 195 & 140 & 0.74 & 0.0647 & 0.0008 & 1.0560 & 0.0180 & 0.1184 & 0.0014 & 0.665 & $721 \pm 8$ & $765 \pm 28$ \\
\hline GS03-065-13 & 291 & 297 & 1.05 & 0.0625 & 0.0016 & 0.8080 & 0.0226 & 0.0938 & 0.0010 & 0.408 & $578 \pm 6$ & $690 \pm 54$ \\
\hline GS03-065-17 & 297 & 252 & 0.88 & 0.0630 & 0.0016 & 0.8780 & 0.0246 & 0.1012 & 0.0012 & 0.431 & $621 \pm 7$ & $707 \pm 54$ \\
\hline
\end{tabular}


Table 2. Hf isotope analyses of Neoproterozoic zircons from the Phan Si Pan granite and Tu Le rhyolite

\begin{tabular}{|c|c|c|c|c|c|c|c|c|c|c|}
\hline Sample & Rock type & $\begin{array}{l}\text { Age } \\
\text { (Ma) }\end{array}$ & ${ }^{176} \mathrm{Hf} /{ }^{177} \mathrm{Hf}$ & $\pm 1 \sigma$ & ${ }^{176} \mathrm{Lu} /{ }^{177} \mathrm{Hf}$ & ${ }^{176} \mathrm{Yb} /{ }^{177} \mathrm{Hf}$ & $\begin{array}{l}\mathrm{T}_{\mathrm{DM} 1} \\
(\mathrm{Ga}) \\
\end{array}$ & $\begin{array}{l}\mathrm{T}_{\mathrm{DM} 2} \\
(\mathrm{Ga})\end{array}$ & $\mathrm{Hf}_{\mathrm{i}}$ & $\varepsilon \mathrm{Hf}_{(\mathrm{T})}$ \\
\hline YB24-05 & Granite & $789 \pm 15$ & 0.282294 & 0.000011 & 0.000800 & 0.024535 & 1.35 & 1.70 & 0.282282 & +0.1 \\
\hline YB27-01 & Granite & $744 \pm 13$ & 0.282225 & 0.000016 & 0.001163 & 0.038888 & 1.46 & 1.89 & 0.282209 & -3.5 \\
\hline YB27-11 & Granite & $715 \pm 13$ & 0.282193 & 0.000007 & 0.001483 & 0.039588 & 1.51 & 1.99 & 0.282173 & -5.4 \\
\hline YB27-13 & Granite & $708 \pm 13$ & 0.282272 & 0.000021 & 0.000848 & 0.022848 & 1.38 & 1.80 & 0.282261 & -2.5 \\
\hline YB29-11 & Granite & $816 \pm 16$ & 0.282273 & 0.000017 & 0.000660 & 0.026871 & 1.37 & 1.72 & 0.282263 & 0.0 \\
\hline LTH26A-08 & Granite & $632 \pm 14$ & 0.282433 & 0.000015 & 0.000541 & 0.017499 & 1.14 & 1.47 & 0.282427 & +1.7 \\
\hline LTH26A-09 & Granite & $825 \pm 17$ & 0.282225 & 0.000015 & 0.000645 & 0.020782 & 1.44 & 1.83 & 0.282215 & -1.5 \\
\hline YB12-01 & Rhyolite & $724 \pm 14$ & 0.282315 & 0.000010 & 0.001148 & 0.038304 & 1.33 & 1.70 & 0.282299 & -0.8 \\
\hline YB12-04 & Rhyolite & $818 \pm 16$ & 0.282281 & 0.000010 & 0.001327 & 0.043816 & 1.38 & 1.73 & 0.282261 & 0.0 \\
\hline YB12-06 & Rhyolite & $793 \pm 15$ & 0.282281 & 0.000009 & 0.001142 & 0.038210 & 1.38 & 1.74 & 0.282264 & -0.5 \\
\hline YB12-10 & Rhyolite & $708 \pm 14$ & 0.282227 & 0.000014 & 0.000648 & 0.021917 & 1.43 & 1.89 & 0.282218 & -4.0 \\
\hline YB12-18 & Rhyolite & $720 \pm 14$ & 0.282261 & 0.000008 & 0.000926 & 0.030538 & 1.40 & 1.82 & 0.282248 & -2.6 \\
\hline YB19A-01 & Rhyolite & $769 \pm 15$ & 0.282246 & 0.000012 & 0.000779 & 0.026009 & 1.41 & 1.82 & 0.282235 & -2.0 \\
\hline YB19A-03 & Rhyolite & $795 \pm 16$ & 0.282246 & 0.000017 & 0.000877 & 0.029793 & 1.42 & 1.80 & 0.282233 & -1.5 \\
\hline YB19A-05 & Rhyolite & $780 \pm 16$ & 0.282329 & 0.000013 & 0.002321 & 0.076132 & 1.35 & 1.67 & 0.282295 & +0.3 \\
\hline YB19A-06 & Rhyolite & $788 \pm 16$ & 0.282299 & 0.000009 & 0.000894 & 0.029255 & 1.34 & 1.69 & 0.282286 & +0.2 \\
\hline YB19A-07 & Rhyolite & $763 \pm 15$ & 0.282246 & 0.000010 & 0.001061 & 0.033368 & 1.42 & 1.83 & 0.282231 & -2.3 \\
\hline
\end{tabular}

The full dataset of the zircon ages are reported in Usuki et al. (2014). 
Table 3. Kangdian basalt starting compositions and modeling conditions

\begin{tabular}{|c|c|c|c|c|c|c|}
\hline Sample & $04 \mathrm{KD} 16-3^{*}$ & $\begin{array}{c}\text { 04KD16-3 } \\
\text { (model EMS1) }\end{array}$ & $99 \mathrm{KD} 22-8^{+}$ & $\begin{array}{c}\text { 99KD22-82 } \\
\text { (model EMS2) }\end{array}$ & $04 \mathrm{KD} 4-24^{*}$ & $\begin{array}{c}\text { 04KD4-24 } \\
\text { (model EMS3) }\end{array}$ \\
\hline $\mathrm{SiO}_{2}(\mathrm{wt} \%)$ & 46.05 & 45.60 & 48.35 & 47.95 & 48.50 & 48.18 \\
\hline $\mathrm{TiO}_{2}$ & 2.44 & 2.42 & 2.78 & 2.76 & 1.47 & 1.46 \\
\hline $\mathrm{Al}_{2} \mathrm{O}_{3}$ & 13.76 & 13.63 & 14.17 & 14.05 & 11.61 & 11.53 \\
\hline $\mathrm{Fe}_{2} \mathrm{O}_{3} \mathrm{t}$ & 17.79 & 17.62 & 13.08 & 12.97 & 12.66 & 12.58 \\
\hline $\mathrm{MnO}$ & 0.30 & 0.30 & 0.17 & 0.17 & 0.18 & 0.18 \\
\hline $\mathrm{MgO}$ & 6.98 & 6.91 & 7.24 & 7.18 & 13.48 & 13.39 \\
\hline $\mathrm{CaO}$ & 8.34 & 8.26 & 10.47 & 10.38 & 9.87 & 9.81 \\
\hline $\mathrm{Na}_{2} \mathrm{O}$ & 2.74 & 2.71 & 1.85 & 1.83 & 1.13 & 1.12 \\
\hline $\mathrm{K}_{2} \mathrm{O}$ & 1.36 & 1.35 & 1.40 & 1.39 & 0.62 & 0.62 \\
\hline $\mathrm{P}_{2} \mathrm{O}_{5}$ & 0.22 & 0.22 & 0.31 & 0.31 & 0.13 & 0.13 \\
\hline $\mathrm{H}_{2} \mathrm{O}$ & & $1 \mathrm{wt} \%$ & & $1 \mathrm{wt} \%$ & & $1 \mathrm{wt} \%$ \\
\hline$f \mathrm{O}_{2}$ & & $\mathrm{FMQ}+2$ & & $\mathrm{FMQ}+2$ & & $\mathrm{FMQ}+2$ \\
\hline Pressure (GPa) & & 1.2 & & 1.2 & & 1.2 \\
\hline
\end{tabular}

